\title{
Jiný pohled na etnicitu jako na biologický koncept: Posun antropologie za koncept rasy'
}

\author{
Another Look at Ethnicity as a biological Concept. \\ Moving Anthropology Beyond the Race Concept
}

\author{
Michael S. Billinger
}

\begin{abstract}
Montagu referred to race as "man's most dangerous myth," while Lévi-Strauss called it "the original sin of anthropology". Although persuasive arguments against the concept of race were made throughout the 20th century, race remains a particular problem for anthropologists who deal in the classification of human populations. Racial terminology has been perpetuated within anthropology largely owing to the fact that, historically, race formed the very core of anthropological study. Despite the conceptual inadequacy of race, the anthropological enterprise has yet to move beyond it as an explanatory tool for understanding human biological variation because of the lack of a conceptual and/or methodological replacement. This article re-analyses historical anthropological literature on ethnicity and biocultural interaction as a replacement for the race concept, and recasts it in the context of modern philosophical and psychological perspectives on population variation.
\end{abstract}

\section{KEYWORDS biocultural, ethnicity, human variation, physical anthropology, race}

Přetrvávání rasových kategorií dramaticky omezuje naše chápání lidské variability a procesů, jež k ní vedou. Rasové klasifikace používané jako prostředek pro vysvětlení lidské variability mají z teoretického hlediska tu chybu, že jsou založeny na apriorním předpokladu, že lidstvo lze rozdělit do jednoznačně definovaných, vzájemně výlučných skupin, at’ už na základě fenotypu nebo genotypu. Je jasné, že různé genetické a morfologické znaky se u různých „populací“ vyskytují s různou frekvencí, ale mezi těmito populacemi dochází k nezanedbatelnému množství genetických výměn, a to na lokální i na globální úrovni. Historie člověka ukázala naši obrovskou mobilitu, a přestože existují různé náhledy na to, jak se jeho populace širrily po světě, všechny hlavní evoluční modely považují za kolébku lidstva východní Afriku. Odtud se raní hominidé nebo moderní lidé (v závislosti na vybraném evolučním modelu $)^{2}$ rozšírili po zemi i po moři. Je vysoce nepravděpodobné, že by se za předpokladu takové

Sociální studia. Fakulta sociálních studií Masarykovy univerzity, 4/2007. S. 23-51. ISSN 1214-813X.

1 Překlad převzat z: „Another Look at Ethnicity as a Biological Concept. Moving Anthropology Beyond the Race Concept“, Critique of Anthropology, 2007, 27 (5): 5-35. (C) 2007 SAGE Publications, www.sagepub.com

2 Zatímco zjištění v oblasti genetiky přesvědčivě ukazují na Afriku jako místo původu moderního člověka, teorie týkající se procesů, jimiž se lidé rozšířili do různých oblastí planety, zůstávají sporné (Collard a Wood 2000, Hawks a Wolpoff 2003). Existují tři hlavní, soupeřící teorie 
mobility mohly ve vymezených geografických oblastech vyvinout takzvané rasové skupiny. V tomto článku si tedy klademe otázku, jež je specifická a nesmírně důležitá z hlediska posunu za rasové paradigma: Existují nějaké přijatelné modely, jež by nám umožnily posunout se konceptuálně za nedokonalý koncept rasy a jež by zároveň byly schopné uchopit jedinečnost každého člověka i univerzálnost lidstva? Tento článek zkoumá všeobecně přehlížená historická pojetí etnicity jako modelu, který konceptualizuje lidskou variabilitu bez rasového rámce, a analyzuje jejich potenciál pro vytvoření explanačního rámce. K potřebnému odklonu od konceptu rasy nedojde, dokud se neobjeví vhodná teorie a metoda, jež postihne nejen zákonitosti evolučních změn, ale také procesy, které $\mathrm{k}$ těmto změnám vedou.

\section{Biokulturní přístup $\mathrm{k}$ lidské variabilitě}

Často se tvrdí, že negativní reakce na koncept rasy vychází především z politické korektnosti, což vede k tomu, že se klasifikace lidských skupin považuje za problematickou pouze kvůli svým sociologickým implikacím. Velmi často se však zůstává opomíjeno nebo nepochopeno, že jak pojem druh, tak poddruh jsou v evoluční biologii obecně kontroverzní (Billinger 2006). Problém konceptu rasy, nebo alespoň toho, jak se používá v souvislosti s moderním člověkem, není sociologický; jedná se o problém interakce mezi biologickou a sociální doménou. To znamená, že podobně jako v první polovině 20. století Deniker (1904), Huxley a Haddon (1935), Hulse (1969) a Montagu (1941, 1942a, 1942b) můžeme tvrdit, že lidstvo představuje jedinečný problém, co se týká jeho ,genofondu“ nebo „reprodukční populace“. Všichni tito autoři tvrdili, že biologické znaky člověka jsou strukturovány spíše etnicitou než působením geografických faktorů, jak se dříve myslelo, a že rasy nebo poddruhy jsou čistě teoretickými abstrakcemi takovýchto skupin. Tento přístup k lidské variabilitě může být nejlépe nazván ,biokulturním“.

V tomto kontextu je důležitý Ernest Hooton (1940, 1946), nebot' jde o vědce, který ve 20. století přispěl asi nejvíce k rozvoji osteologické metody výzkumu člověka v severní Americe, a zmíněný biokulturní přístup byl v rozporu s jeho důrazem na pojímání fenotypu

fylogeneze člověka. Hypotéza ,ven z Afriky“ je nejoblíbenější. Je založena na důkazu mitochondriální DNA Canna a kol. (1987) a spočívá v tom, že moderní člověk se vyvinul v Africe přibližně před 200000 lety a rozšiříl se do Evropy a Asie ve dvou nebo třech vlnách. Jeho stěhování začalo přibližně před 100000 lety a do Asie dospěl přibližně před 60000 lety. Multiregionální hypotéza je antropologickým modelem založeným primárně na morfologických spíše než na genetických důkazech, jež tvrdí, že za původem ras stojí migrace Homo erectus z Afriky před dvěma miliony let. Homo erectus se potom rozdělil do mnoha různých skupin, jež se rozšířily do severozápadní Afriky, Asie a Evropy. Někdy před 250000 až 200000 lety se tyto skupiny H. erectus prostřednictvím př́rodního výběru adaptovaly na místní prostředí, čímž vzniklo množství morfologických variací odlišných od původní podoby $H$. erectus. Podle tohoto modelu se tyto oddělené populace postupně vyvinuly do regionalizovaných variant Homo sapiens, raných předků moderních ras (Wolpoff a Caspari 1997, Wolpoff a kol. 1984). O něco později vznikla hypotéza ,zahrady v Edenu“ (která se zčásti shoduje s multiregionální hypotézou), jež tvrdí, že moderní Homo sapiens se vyvinul ze subpopulace Homo erectus a po několik desítek tisíc let se pomalu šíril. Vznikly tak oddělené dceřiné populace, z nichž potom dál expandoval (Harpending a kol. 1993: 484). 
jako základní jednotky antropologického výzkumu lidské variability. ${ }^{3}$ Ukazuje se, že podobné údaje o fenotypu mají význam pro studium malých a regionálně omezených historických vzorků kostí, ale když se používají u rozsáhlejších taxonomických nebo fylogenetických studií, přinášejí s sebou řadu problémů. Biokulturní př́stup je naopak založen na moderních genetických principech. Ashley Montagu byl v tomto př́stupu přeborníkem: Aldous Huxley napsal v úvodu k jeho knize Man's Most Dangerous Myth (1942a), že antropologičtí autoři se mnohdy dopouštějí př́ilišného zjednodušování, kdežto Montagu trval na existenci mnoha vzájemně provázaných příčin. $\mathrm{K}$ tomuto zjednodušování dochází $\mathrm{v}$ antropologii dosud. Přestože antropologové mají při studiu člověka co do činění jak se sociokulturními, tak i s biologickými problémy, ucelený biokulturní př́stup byl dosud značně přehlížen.

$\mathrm{Z}$ antropologických kruhů vedl soustředěný útok proti ideji rasy jako první Franz Boas, a to nejen na základě filozofické argumentace, ale i prostřednictvím rozsáhlého souboru empirických dat. Mezi lety 1910 a 1913 publikoval Boas mnoho článků (viz Boas 1911, 1912, 1940) pod názvem „Tělesné změny potomků imigrantư““ (Changes in the Bodily Form of Descendants of Immigrants). Jejich soubor se stal antropologickou klasikou, nebot' dokazoval plasticitu lidského vzhledu. Premisou tohoto projektu bylo podle Boase (1911: 1) tvrzení, že „základní data, která je ve výzkumu tohoto typu zapotřebí získat, se musí týkat rozdílů $\mathrm{v}$ tělesné stavbě imigrantů, kteří přicházejí do tohoto státu v různých dobách, a rozdílů, k nimž dochází u jejich potomků v tomto státě narozených“. Boas analyzoval antropometrická data přibližně 13000 evropských imigrantů a jejich potomků ve Spojených státech, přičemž se zaměřoval především na tvar hlavy žijících jedinců. Aby zjistil změnu tělesné stavby v čase, používal cefalický index (šǐřka hlavy se podělí její délkou a výsledné číslo se vynásobí stem). Dřive se předpokládalo, že cefalický index je dědičný a odolný vůči vlivům prostředí (Gravlee a kol. 2003, Halloway 2002). Proto by se průměrná hodnota tohoto indexu neměla u jednotlivých lidských typů měnit. Skupiny imigrantů studované během tohoto výzkumu byly vybrány tak, aby představovaly „co nejrozdílnější evropské typy“ a zároveň největší skupiny imigrantů ve Spojených státech té doby. ${ }^{4}$

Zdá se, že získanými výsledky, jež byly podrobeny důkladné statistické analýze, byl překvapen i sám Boas:

Z praktického hlediska se zdálo být nanejvýš důležité zjistit, zda má americké prostředí př́znivý či nepř́znivý vliv na potomky imigrantů. Výzkum ukázal daleko více, než jsme očekávali. Nejenže

3 Podle Hootona: Rasové klasifikace, jestliže mají být používány vědci nebo kýmkoliv jiným pro zlepšení a ulehčení bojů mezi lidmi, se musí podřídit starým, přirozeným a vcelku správným taxonomickým metodám. Musí být založeny na pozorovatelných znacích lidských fenotypů. Tyto klasifikace však, mají-li být validní a smysluplné, musí být v souladu s objevy moderní genetiky. Jestliže se předpokládá, že fyzická uskupení lidí jsou založena na kombinaci dědičných spíše než druhotných znaků, je nezbytné dokázat, že dotčené fenotypy velmi pravděpodobně představují viditelný projev genetických faktorů - že tyto fenotypy odkazují na genotypy, které jsou za ně zodpovědné spolu s nevyhnutelnými a modifikujícími vlivy prostředí (1946: 441).

4 Boas (1911: 55-6) klasifikoval skupiny imigrantů jako: Středoevropané - Češi, Slováci a Mad'aři a Poláci; Židé (z Ruska, Polska, Německa, Rakouska, Švýcarska a Rumunska); Středozemci (Sicilané, Neapolitánci); Skoti. Není však jasné, jak Skoti do této typologie ve skutečnosti zapadají. 
dochází ke zjevným změnám v rychlosti vývoje imigrantů, ale také ke značné změně v jejich typu - čili ke změně, jež nemůže být připsána výběru nebo míšení, ale kterou lze vysvětlit pouze přímým poukazem na vliv prostředí (1911: 2).

Analýza rozsáhlých dat, jež nasbíral, vedla Boase (1912: 530) k formulaci mnoha závěrů; pro tuto diskuzi jsou však nejvýznamnější jeho závěry založené na morfologii vycházející z výpočtu cefalického indexu:

1. Potomci imigrantů narození v Americe se typem liší od svých rodičů narozených $v$ cizině. Změny vyskytující se u různých evropských typů jsou různé. Vzniknou v raném dětství a přetrvávají po celý život (Tabulka 1).

2. Vliv amerického prostředí roste s dobou, která uplynula mezi príchodem matky do země a narozením dítěte (Graf 1$)$.

Boasovy výsledky byly složité a jeho metodologie často nejasná, a proto byly jeho původní závěry mnohokrát kritizovány (Boas 1911: 533). To jej donutilo k tomu, aby v roce 1928 celý svůj datový soubor zveřejnil.

Tabulka 1: Zvýšení (+) nebo snižení (-) měr dětí imigrantů narozených ve Spojených státech ve srovnání s imigranty z Evropy, váženo počtem př́padu (převzato z Boas 1911: 56, 1940: 60). Míry jsou uváděny $\vee$ milimetrech $(\mathrm{mm})$.

\begin{tabular}{|c|c|c|c|c|c|c|c|}
\hline Rasa/národnost & Pohlaví & $\begin{array}{l}\text { Délka } \\
\text { hlavy }\end{array}$ & $\begin{array}{l}\text { Šĩ̃ka } \\
\text { hlavy }\end{array}$ & $\begin{array}{l}\text { Cefalický } \\
\text { index }\end{array}$ & $\begin{array}{l}\text { Šr̃rka } \\
\text { tváře }\end{array}$ & $\begin{array}{c}\text { Tělesná } \\
\text { výška }\end{array}$ & Hmotnost \\
\hline \multirow[t]{2}{*}{ Češi } & Muži & $-0,7$ & $-2,3$ & $-1,0$ & $-2,1$ & $+29,0$ & 170 \\
\hline & Ženy & $-0,6$ & $-1,5$ & $-0,6$ & $-1,7$ & $+22,0$ & 180 \\
\hline \multirow[t]{2}{*}{ Mad'ar̆i a Slováci } & Muži & $-0,5$ & $-1,1$ & $-0,7$ & $-1,0$ & $+59,0$ & 54 \\
\hline & Ženy & $-0,3$ & $-0,9$ & $-1,0$ & $-2,2$ & $+10,0$ & 38 \\
\hline \multirow[t]{2}{*}{ Poláci } & Muži & $-0,3$ & $+0,2$ & $+0,2$ & $+0,7$ & $+42,0$ & 22 \\
\hline & Ženy & $+0,9$ & $-1,6$ & $-1,4$ & $-1,3$ & $+17,0$ & 27 \\
\hline \multirow[t]{2}{*}{ Židé } & Muži & $+2,2$ & $-1,8$ & $-2,0$ & $-1,1$ & $+17,0$ & 654 \\
\hline & Ženy & $+1,9$ & $-2,0$ & $-2,0$ & $-1,3$ & $+15,0$ & 259 \\
\hline \multirow[t]{2}{*}{ Sicilané } & Muži & $-2,4$ & $+0,7$ & $+1,3$ & $-1,2$ & $-1,0$ & 188 \\
\hline & Ženy & $-3,0$ & $+0,8$ & $+1,8$ & $-2,0$ & $-5,0$ & 144 \\
\hline \multirow[t]{2}{*}{ Neapolitánci } & Muži & $-0,9$ & $+0,9$ & $+0,9$ & $-1,2$ & $+6,0$ & 248 \\
\hline & Ženy & $-1,7$ & $+1,0$ & $+1,4$ & $-0,6$ & $-18,0$ & 126 \\
\hline \multirow[t]{2}{*}{ Skoti } & Muži & $+1,4$ & $-0,5$ & $-0,8$ & $-1,5$ & $+18,0$ & 39 \\
\hline & Ženy & $-0,3$ & $+0,3$ & $+0,2$ & $+1,9$ & $+39,0$ & 33 \\
\hline
\end{tabular}

Výsledky Boasovy studie zůstávají rozporuplné dodnes. Dvě nedávné analýzy jeho dat z roku 1928 znovu probudily debatu o vlivu environmentálních faktorů na velikost a tvar lebky. Sparks a Jantz (2002) použili na Boasova data moderní statistické postupy a došli k závěru, že dědičnost je silnější, než Boasovy výsledky ukazují. Gravleeho a kol. (2003) přivedla statistická analýza naopak ke konstatování, že Boasovy výsledky jsou v podstatě 
správné. Pokračující debata o tom, jaký je poměr mezi faktory dědičnosti a faktory prostředí při utváření tělesné stavby, dokládá složitost tohoto vztahu, který se antropologové pokoušejí rozšifrovat již déle než jedno století. Já tvrdím, že nejlepším modelem, který vztah mezi oběma vysvětluje bez využití konceptu rasy, je biokulturní koncept etnické skupiny, přestože $\mathrm{i}$ tento koncept je s největší pravděpodobností třeba podrobit kritice.

V roce 1900 publikoval hlavní knihovník Národního muzea př́rodní historie v Paříži Joseph Deniker knihu Lidské rasy (The Races of Man, 1904), v níž se zabýval studiem antropologie a etnografie a problémy rasové klasifikace. Tato kniha představuje pravděpodobně první uveřejněnou polemiku obsahující tvrzení, že tradiční antropologický koncept rasy by měl být nahrazen pojmem etnicita. Nejpozoruhodnější na této knize je to, jak Deniker zjevně předjímá mnohé debaty, které měly $\mathrm{v}$ biologických vědách a $\mathrm{v}$ antropologii vyvstat $\mathrm{v}$ polovině dvacátého století a které se táhly až do století jednadvacátého, když upozorňuje na řadu problémů týkajících se systematické taxonomie v obecném smyslu a konkrétně pak její aplikace na člověka.

Graf 1: Cefalický index dospělých mužu narozených v cizině a v Americe usporádaný podle doby, která uběhla mezi narozením a migrací u Židư, Sicilanů a Neapolitánců (údaje převzaty z Boas 1911: 61, 1940: 61)

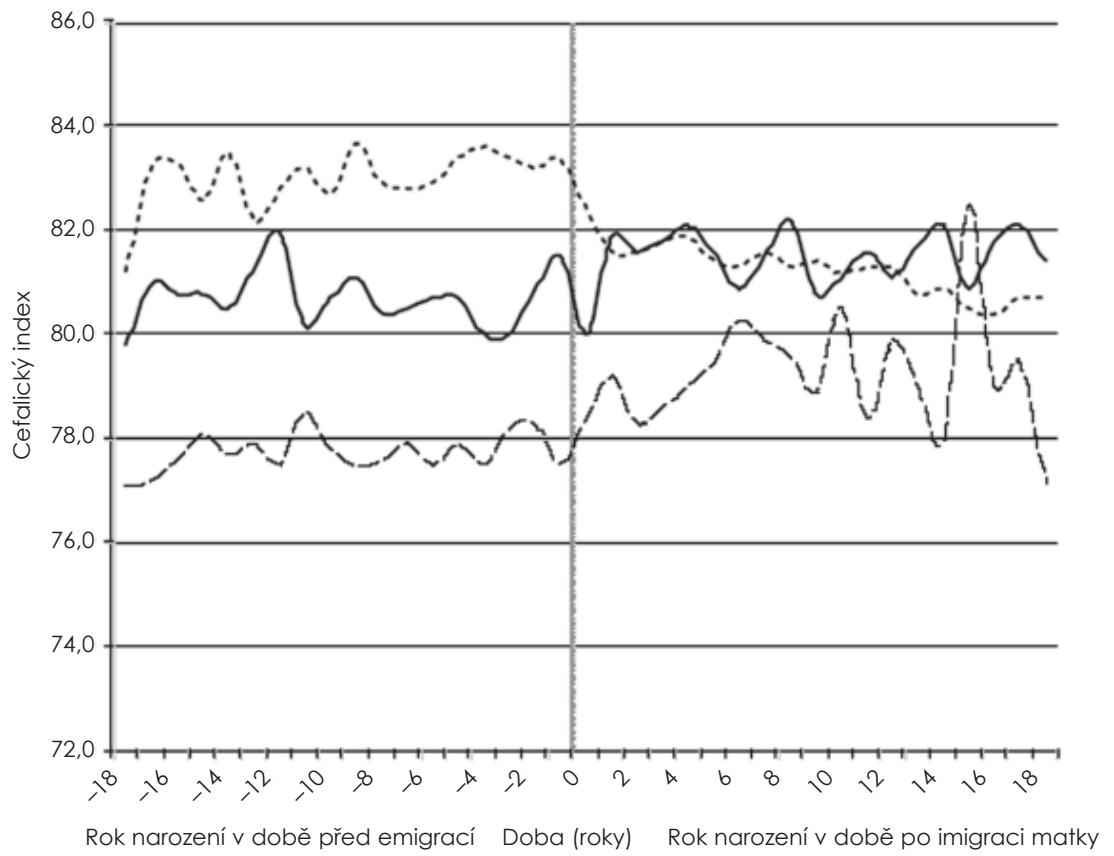

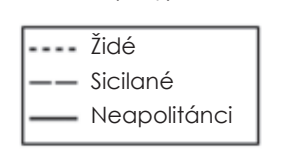


Deniker si uvědomoval velkou kulturní a biologickou variabilitu lidských skupin a byl skeptický k pokusům vytvořit systematický přehled všech obyvatel světa, at' už na základě sociálních nebo fyzických charakteristik. Zajímal se především o základní otázky týkající se charakteru lidské skupiny a jejího vztahu k zoologickým jevům, přičemž se ptal:

Představují tyto reálné a smysly rozeznatelné lidské skupiny společenství jedinců, která i přes určité drobné odlišnosti mohou být tím, co zoologové nazývají „druhy“, „poddruhy“, „varietami““v př́padě divokých zviŕăat nebo „rasami“ $\mathrm{v}$ prípadě domácích zvírat? Nemusíme být profesionálními antropology, abychom na tuto otázku odpověděli záporně. Jedná se tu o etnické skupiny vytvořené prostřednictvím společného jazyka, náboženství, sociálních institucí atd., v žádném případě o zoologické druhy (Deniker 1904: 2-3).

Deniker považuje rasy za teoretická uskupení, narozdíl od etnických skupin a jejich př́islušníků, které vnímá jako empiricky pozorovatelné. $\mathrm{K}$ argumentu proti pojímání lidských skupin jako zoologických druhů Deniker (1904: 3-4) dodává, že v podstatě neexistují typické exempláře jednotlivých teoretických rasových skupin:

Jsou to tedy jednotky, teoretické koncepce, přesně jako „druhy“ v zoologii; pouze namísto př́mého př́stupu k „typům“ těchto druhů, jako je tomu u zoologických skupin, se musíme spokojit s pouhými aproximacemi, nebot' jen málokdy potkáme jedince, jenž by ztělesňoval somatický typ, k němuž patř́i. Nejčastěji se setkáváme se subjekty, jejichž podoba se změnila míšením a křřžením a u nichž kromě dvou nebo tř́ typických rysů najdeme pouze chaotickou směs znaků, které nevyjadřují nic zvláštního... Ve skutečnosti téměř neexistují lidé, kteří by představovali „somatické jednotky“ srovnatelné se zoologickými ,druhy“.

Nejenže se tedy Deniker (1904: 4) domnívá, že vnější fyzické znaky mají pouze malý heuristický význam, co se týče skutečných biologických vztahů, ale tvrdí, že žádný ze zoologických termínů - „druhy“, „,variety“ nebo „rasy“ - není vhodný pro použití v souvislosti s rodem Homo.

Tato námitka proti používání zoologické terminologie typu „druhy“ nebo „variety“ nejen u Homo sapiens, ale u celého rodu Homo, byla založena na Denikerově pojetí zoologických druhů žijících pod vlivem prírody; ona přirozená uskupení mohou vznikat pouze u divokých zvírat. Naopak rasa se mohla vyvinout jen díky umělým podmínkám provázejícím domestikaci zviŕăat, jež daly vzniknout jasně vymezeným plemenům (Deniker 1904: 4). Deniker v podstatě tvrdí, že člověk není podřízený přírodě stejným způsobem jako zvířata - přestože lidé žijí v umělých prostředích, jsou to prostředí, která si vytvořili sami a která nevznikla působením vnějších sil. Jelikož si však lidé tyto podmínky sami vybrali a jde o prostředí, které nevzniklo domestikací, nelze tělesnou stavbu člověka prímo srovnávat se zviŕaty. Deniker (1904: 4) především tvrdí, že „data týkající se vzniku variet, druhů a ras tak mohou být vztažena k morfologickému studiu člověka jen s jistými výhradami““.

Denikerovi nezůstalo utajeno, že rasa není jen antropologickým problémem, ale jednou z obecných biologických aplikací (Billinger 2006) a uvědomoval si tuto skutečnost již před celým stoletím: 
Mějme na paměti, že dokonce ani hranice mezi druhy, varietami (geografickými a jinými) a rasami nejsou zdaleka jasné. Navíc se jedná o otázku obecné biologie, s níž se botanika či zoologie nevyrovnaly o mnoho lépe než antropologie (1904: 5).

Deniker vysvětluje, že hlavní překážka pro vytvoření přesné klasifikace lidských skupin spočívá $\mathrm{v}$ tom, že odlišení přirozených biologických skupin se zakládá na prokázané možnosti vzájemného oplodnění. Přestože je možné dedukovat, že se všechny lidské skupiny mohou mezi sebou kř́žit, jak Darwin tvrdil ve své knize O pưvodu člověka (1971: kap. 7), Deniker předpokládá, že možnost křížení mezi lidmi z různých geograficky vymezených populací není možné experimentálně dokázat. Deniker také nesouhlasí s Darwinovým (1888: 280) tvrzením, že je ,téměř lhostejné, zda jsou takzvané lidské rasy jako takové jen označené, nebo zda jsou zařazeny jako druhy či poddruhy, přričemž poddruhy se zdají být adekvátnějšíi“. Přesněji řečeno Deniker termín poddruhy odmítl:

Slovo „rasa“ se dnes téměř všeobecně používá k označení různých fyzických typů lidí. Dávám mu přednost před slovem ,poddruh“, i když znovu zdůrazňuji, že není žádný zásadní rozdíl mezi těmito dvěma slovy a slovem „druh“. (1904: 7)

Přestože Deniker nesouhlasil s Darwinem ohledně terminologie, byl stejně jako on toho názoru, že každé podobné rozdělení lidí je arbitrární, a v důsledku toho se domníval, že debaty mezi těmi, kdo věří, že lidé tvoří jediný druh, a těmi, kdo věří, že lidské rasy jsou různými druhy, nemají praktický význam:

Celý tento dávný spor mezi monogenisty a polygenisty se zdá být poněkud scholastický a zcela neplodný a zbytečný. Táž nemnohá a špatně prokázaná fakta se objevují vždy znovu a znovu, interpretována každým diskutujícím způsobem, jenž zapadá do jeho argumentu, a někdy vedena mimovědeckými úvahami. (1904: 7)

O více než sto let později zůstává tento problém v jádru pořád stejný - nedostatečně prokázaná fakta o lidské evoluci se objevují znovu a znovu a často jsou používána nekriticky. Ve svém pokusu posunout studium lidské variability se Deniker (1904: 8-9) domnívá, že člověk nemůže být adekvátně studován pouze prostřednictvím zoologie nebo sociologie. Tvrdí, že etnické skupiny jsou výsledkem napětí mezi dvěma faktory: variabilitou neboli různorodostí a dědičností neboli opakováním podobného. Člověk tedy musí být studován jako jedinec patřící jak k zoologické skupině, tak k uskupení jedinců v rámci společností.

V tomto směru byla antropologie, zvlášst' v Evropě, považována za studium somatických charakteristik rodu Homo jako celku nebo v jeho vztahu k ostatním živočichům, zatímco etnografie či etnologie se zabývaly studiem etnických charakteristik. Deniker chtěl obě tyto oblasti zkoumání propojit, a tak vytvořit ucelenější pohled na lidskou variabilitu: „Dochází však ke konvergenci lidských znaků a my dodnes nalézáme stopy divošství i u těch nejcivilizovanějších lidí. Etnická fakta proto nemohou být brána v úvahu odděleně“ (1904: 9). Denikerovým cílem byl úplný sociální a biologický popis každé ze známých lidských populací. V této klasifikaci se ale při popisu toho, co již dříve nazval etnickými skupinami, znovu vrátil k termínu „rasa“ a svou klasifikaci navíc založil výhradně na vnějších, fyzických znacích. Hlavním nedostatkem jeho schématu byla asi chybějící definice etnické skupiny, což, 
jak se zdá, bylo důvodem, proč samotný Deniker tento termín nepoužil při popisu variability lidstva, jíž si byl vědom.

Huxley a Haddon, přestože nezmiňují ranější Denikerovo dílo, vnímají vztah mezi zoologickým pojetím rasy a nemožností ho aplikovat na lidské populace velmi podobně, i když se zjevně větší naléhavostí:

Slovo „rasa“ brzy získalo jistou neurčitost, které se již nikdy nezbavilo. A právě spojení této neurčitosti s občasným používáním tohoto slova některými vědci předchozí generace a s předpokládanou analogií mezi zoologickými a lidskými „rasami“ vedlo ke zvláštní oblibě tohoto slova u skupiny autorů, kteří se zabývají vědeckými tématy, aniž by byli dostatečné vědecky vybaveni. Od nich pak sestoupilo do literatury s mnohem ostřejším nacionalistickým vyzněním (1935: 19).

Jejich nejvážnějším obviněním antropologických př́istupů k taxonomii bylo, že se antropologie dostatečně nezajímá o aplikaci moderní genetické teorie (evolucionistické syntézy) ${ }^{5}$ na problémy biologie (Huxley a Haddon 1935: 60). V pokusu přivést antropologické studium do náruče mendelovské genetiky si Huxley a Haddon položili za cíl rozpracovat ,základní odlišnost mezi fenotypem, neboli viditelnou podobou organismu, a jeho genotypem, neboli dědičnou stavbou“" (1935: 74).

Huxley a Haddon argumentovali tím, že prakticky všechny lidské skupiny jsou smíšeného původu, a proto u všech panuje značná genetická variabilita. Při studiu variability je pak podle nich nejdůležitější zaměřit se na její rozsah:

Podle očekávání mendelovských genetiků, obeznámených s důkazy o dědičnosti a migračních zvycích člověka, by měly existovat skupiny s velkou mírou variability, jež je zodpovědná za zvláštní znaky kvalitativního i kvantitativního charakteru; takové skupiny je možné od sebe odlišit pouze pomocí statistických metod. Spočítat průměrné hodnoty znaků je u těchto skupin sice užitečné, ale z teoretického hlediska nepř́liš důležité. Rozsah variability znaků má daleko větší praktický význam, stejně jako rozsah kvalitativně odlišných smíšených typů. Ona dvě výsledná pojetí „,rasy“ nebo etnika se od sebe zásadně liší (1935: 104).

Důraz na rozsah variability spíše než na průměrné údaje ve smíšených populacích vede Huxleyho a Haddona k tvrzení, že rasa je nereálnou entitou, což je podnítilo k formulaci známého výroku: „Za těchto okolností je velmi žádoucí, aby byl termín rasa používaný pro lidské skupiny vypuštěn z vědeckého slovníku“ (1935: 107).

Význam jejich argumentu spočíval zčásti na jimi samými vymezených sociálních aspektech rasy, poskytli ale také konkrétní genetické argumenty, přičemž jako hlavní podpůrný faktor uváděli rozsáhlou migraci lidí:

5 Moderní chápání biologické variability v rámci biologických věd vychází z podstatné redefinice této domény, k níž došlo ve 40. letech 20. století přijetím „evoluční syntézy”, jež vznikla kombinací př́rodního výběru a genetiky při studiu druhů a jejich vzniku. Jejími hlavními tvůrci byli Theodosius Dobzhansky, Julian Huxley, Ernst Mayr, Georg Gaylord Simpson a Bernhard Rensch (viz Mayr 1997, 2004). Toto přepracování evolučního chápání spojilo darwinismus s mendelovskou genetikou a poskytlo tak mechanismus umožňující porozumět procesům přírodního výběru. 
U jiných živočichů byla „rasa“ nahrazena termínem poddruh. U člověka jsou však v důsledku migrace a křižení změny tak plynulé, že žádný podobně jednoznačný termín, který by bylo možné použít k popisu současné situace, není př́pustný. Pozorujeme jen relativní izolaci skupin, jejich migraci a kř́žžení. V následujícím textu se schválně vyvarujeme používání slova rasa a pro obecné účely budeme používat termín (etnická) skupina nebo lid. (Huxley a Haddon 1935: 107-108)

Vztah mezi fenotypem a genotypem představuje velký problém jak pro antropology, tak pro biology dodnes, a když se tito vědci zabývají podobnými smíšenými etnickými komunitami, neodpovídají klasifikace založené na fenotypických znacích, zvláště pak na popisu měkkých tkání, jasným genetickým důkazům, které se ale daleko obtížněji zjišt’ují:

Metoda vycházející z fenotypických znaků a metoda stavící na genetických důkazech se liší svou vědeckou hodnotou a možností praktického uplatnění. Pokusit se o klasifikaci na základě vnějších znaků je daleko jednodušší a jedná se o jedinou metodu, kterou je možné použít okamžitě (navíc představuje první a nezbytný krok k vytvoření klasifikace vycházející z genetických informací). Je však méně uspokojivá $\mathrm{z}$ vědeckého hlediska, což je dáno částečně tím, že zdánlivě podobné znaky mohou být určovány odlišnými geny, respektive že tentýž gen může vést v kombinaci s jinou konfigurací dalších genů naopak ke vzniku jiných znaků. Kromě toho je každý znak výsledkem interakce mezi geneticky podmíněnou stavbou těla a prostředím. Rozlišit z genetického hlediska nedůležité působení prostředí od stěžejního vlivu genů je obtížné u všech organismů, zvláště pak u člověka, kde sociální a kulturní prostředí - u lidského druhu jedinečné - hrají převládající roli (Huxley a Haddon 1935: 108-109).

Svým zaměřením jak na kulturní, tak na fyzické prostředí, jež podle nich hrají zásadní roli při utváření genetické výbavy a tělesné stavby lidských populací, připomínají perspektivu, kterou zastával ve svých imigračních studiích Boas.

Huxley a Haddon tvrdili, že proces klasifikace je arbitrární a že každé dělení lidských skupin prostřednictvím jakýchkoliv kritérií vede ke vzniku klasifikace, jež může jen stěží odpovídat jakýmkoli jiným kritériím. Proto se zcela jasně vyjádřili, že: „Pokud je rasa vědeckým termínem, pak musí být geneticky podložená، (1935: 129). Ovšem zatímco Deniker odmítl používání termínu ,poddruh“ při popisování lidských populací, Huxley a Haddon určili tomuto termínu stejnou hypotetickou roli, jakou Deniker propůjčil rase. Když se však zabývali skutečných lidskými populacemi, upřednostňovali opět termín ,etnická skupina“:

Abychom se vyhnuli nešt'astným konotacím slova rasa, je lepší použivat termín poddruh. Mělo by však být zdůrazněno, že existence takovýchto lidských poddruhů je čistě hypotetická. V současnosti nikde neexistuje lidská skupina, která by přesně odpovídala systematické kategorii poddruhu u živočichů, nebot' různé původní poddruhy se opakovaně a nepřetržitě křrižily. Současné populace by tedy měly být označovány neutrálním termínem etnická skupina (1935: 136).

Jejich představa klasifikace etnických skupin byla kvantitativní spíše než kvalitativní a spíše trrírozměrná než založená na jednom znaku:

Abychom to shrnuli, etnická klasifikace by měla v první řadě poskytovat odpovídající popis fyzických charakteristik různých regionálních skupin ve smyslu jistých předem smluvených charakteristik. $\mathrm{Z}$ toho důvodu nutně potřebujeme nejen průměrné hodnoty a statistické odhady variability jednotlivých znaků, ale také křivky ukazující jejich rozložení v odpovídajících vzorcích populace. 
Dále jsou zapotřebí číselné odhady (korelační koeficienty) míry asociace mezi různými znaky. Tento postup nám umožní vytvořit popisnou klasifikaci lidských populací v různých geografických regionech světa, tedy etnických skupin s určitými fyzickými zvláštnostmi (Huxley a Haddon 1935: 143).

Tento způsob uvažování o lidské variabilitě umožnil určitou míru flexibility, která nebyla v předchozích taxonomických úvahách obvyklá. Huxley a Haddon věřili, že u rigidních taxonomií, které neberou v úvahu mikroevoluční procesy, je možné použít typologii, pokud si jsou výzkumníci vědomi toho, že typy nejsou statické nebo čisté, ale že jsou jen teoretickými modely: ${ }^{6}$

Z této popisné klasifikace pak bude možné abstrahovat ideální typy, o nichž se předpokládá, že svými kombinacemi vytvořily existující smíšené populace, a hypotetické vyšší a nižší poddruhy, do nichž se, jak je nutno předpokládat, lidský druh v průběhu svého vývoje diferencoval. Tyto ideální typy však nesmí být chápány jako neměnné a poddruhy jako někdy v minulosti geneticky čisté (1935: 143).

Toto napětí mezi pojetím typu a uvědomováním si mikroevolučních sil je možná hlavní překážkou, jež brání v posunu od tradičních pokusů o klasifikaci; Huxley a Haddon ovšem jasně ukázali, že pro pochopení biologických skupin a jejich relativně rychlého vývoje byla klíčová genetika a ne morfologie. Problémem jejich metodologie však bylo, že v době před objevením DNA nedokázali získat přímý př́stup ke genetickým informacím a při vytváření své etnické klasifikace byli nuceni spoléhat se především na variabilitu měkkých tkání (charakter a barvu vlasů, barvu kůže, tvar a barvu očí), fyziologických a psychologických faktorů (tělesné teploty, tepové frekvence, dýchání, začátku puberty, metabolických změn, barevného vidění, smyslového vnímání), malého množství antropometrických proměnných (výšku postavy, tvaru hlavy, tvaru nosu) a údajů o krevní skupině.

Nejucelenější pojetí etnické klasifikace vytvořil Montagu (1942a, 1942b, 1962, 1997), který také objasnil, proč je tato klasifikace hodnotnější než klasifikace rasová. Montagu nastiňuje a věrně sleduje argumenty svých předchůdců, přičemž se soustředí jak na otázky taxonomie, o kterých pojednával Deniker, tak na genetické problémy rozpracované Huxleym a Haddonem (viz především Montagu 1962: 921-922). Montagu jasně a výstižně kritizoval koncept rasy a tuto srozumitelnost přenesl i do své argumentace, v níž prosazoval etnicitu jako náhradu za rasu. Předchozí pokusy začlenit sociální svět do struktury biologických sys-

6 Přestože se Huxley a Haddon ve své diskuzi o ideálním typu nezmiňují o Maxu Weberovi, používají tento pojem velmi podobným způsobem jako on. Weber věří, že koncepty musí být jasné, výlučné a přesně definované, aby vědecká mysl porozuměla realitě. Dokonalost a čistota ideálního typu vedou k jejich jasnosti, výlučnosti a srozumitelnosti (Schwartz a kol. 1995: 425). Podle Webera: ...ideální typ je získán jednostranným stupňováním jednoho či několika hledisek a sloučením množství jednotlivých difusních a diskrétních jevů, které se vyskytují tu více, tu méně, místy vůbec ne, a které se spolu s jednostranně zdůrazněnými hledisky spojují ve vnitřně jednotný myšlenkový obraz [Gedankenbild]. Ve své pojmové čistotě se tento myšlenkový obraz [Gedankenbild] nikde ve skutečnosti empiricky nevyskytuje, je to utopie a pro historickou práci vyvstává úkol, aby v každém jednotlivém případě zjistila, jak se skutečnost k onomu ideálnímu obrazu blíží či jak je mu vzdálena (1949: 90; český překlad M. Havelka in Weber 1998: 44). 
témů doplatily na to, že neexistovala definice termínu „etnická skupina“, což byl problém, který Montagu rozpoznal a pokusil se napravit, tvrdíce: „Etnická skupina představuje část populace druhu, u níž probíhá proces genetické diferenciace. Jedná se o skupinu jedinců, kteří mají schopnost kř́̌̌it se a postupně se mísit s ostatními etnickými skupinami, přičemž dochází k dalšímu genetickému slučování a k další diferenciaci“ (1942b: 374). Přesněji definuje Montagu etnickou skupinu jako:

[J]ednu z řady populací jediného druhu Homo sapiens, z nichž si každá uchovává své fyzické a kulturní odlišnosti prostřednictvím izolačních mechanismů, jako jsou geografické a sociální bariéry. Tyto odlišnosti se mění se změnou působení geografických a sociálních bariér, jež byly příčinou původních genetických rozdílů. Kde tyto překážky působí s nižší intenzitou, tam se sousední skupiny vzájemně sbližují nebo křǐzí. Kde překážky působí s vysokou intenzitou, tam si etnické skupiny zachovávají svou odlišnost nebo jedna druhou nahrazují co se týče geografického prostoru nebo místa v rámci ekosystému (1942b: 375).

Montagu (1941: 247) vyjadřuje svůj nesouhlas s konceptem rasy přímočaře a kvalifikovaně. Jeho přesvědčení, že jde o zásadně špatný koncept, je založeno na třech základních premisách: (1) jedná se o umělý koncept, (2) který neodpovídá zjištěním o lidské variabilitě a (3) vede $\mathrm{k}$ chaosu a neustálému opakování stejných chyb. Tyto argumenty jsou pevně zakotveny v předpokladu stěžejního postavení genetických faktů, které v antropologických klasifikacích té doby chybělo:

Neodkladnou povinností fyzického antropologa, který se zajímá o původ lidské variability, je zkoumat problém, jejž lidská variabilita představuje, ne jako taxonomický, ale jako genetický, nebot' variabilita, která se obecně nazývá „rasou“, je procesem, jenž může být správně popsán pouze prostřednictvím četnosti výskytu jednotlivých genů ve skupinách představujících adekvátní izolované populace. Pokud „rasa“ a „rasová" variabilita mohou být nejlépe popsány pomocí četnosti genů, potom patří $\mathrm{k}$ našim nejdůležitějším povinnostem zjistit, jakou roli při vzniku této variability hrají primární a sekundární faktory (Montagu 1942b: 373).

V této perspektivě se odráží naprosté odmítnutí Hootonova tvrzení, že taxonomie musí vycházet $\mathrm{z}$ úrovně fenotypu.

Montagu svou argumentaci v průběhu dvaceti let ještě zdokonalil. V souvislosti s taxonomickými problémy, o nichž se jako první zmiňoval Deniker, Montagu podobně jako on tvrdí, že na nás působí stejné evoluční síly jako na všechny ostatní druhy, ale způsobem, jenž byl pozměněn kulturou:

Na úvod bych měl asi ujasnit, že jsem stejně jako většina biologů přesvědčen o tom, že evoluční faktory - podobné těm, jež působily při vzniku ras u jiných živočišných druhů - hrály svou roli také u lidského druhu. Je zde však jeden velký rozdíl, totiž důsledky plynoucí ze vstupu člověka do jedinečné zóny adaptace, $v$ níž exceluje daleko více než všechna ostatní stvoření, do zóny kultury, představující část prostředí vytvořenou člověkem (1962: 919).

Toto rozlišení mezi prostředím $\mathrm{v}$ přirozeném stavu, jemuž jsou podřízeni všichni nedomestikovaní živočichové, a umělým prostředím vytvořeným lidskou řečí a technologií je 
klíčové pro chápání lidské variability jako protikladu k obecné druhové variabilitě. Podle Montagua je lidská variabilita jedinečná zejména z důvodu mobility a sociálního výběru:

Zdá se tedy prokázané, že lidská kulturní činnost vnesla do procesu diferenciace člověka na rasy prvky, které pozměnily koncové produkty tohoto procesu tak zásadním způsobem, že už není možné jej srovnávat s procesy rasové diferenciace prítomnými u nižších živočichủ. Faktory mutace, prírodního výběru, genetického driftu a izolace sehrály při vývoji člověka svou roli. Ale stejně tak sehrály svou roli i takové faktory, jako je neustále se zvyšující mobilita, křrižení a sociální výběr. A právě $\mathrm{v}$ důsledku těchto a jim podobných faktorů, alespoň tak se mi to vždy zdálo, není možné vztahovat termín „rasa“ na většinu současných lidských populací (1962: 919).

Právě kvůli těmto faktorům Montagu tvrdí, že tradiční biologická terminologie typu „rasa“ či „poddruh“ je pro biologii člověka zcela nevhodná.

Montagu objasňuje, že jeho pohled na lidskou variabilitu a jednotu druhu nepopírá, že se lidské skupiny od sebe liší. Jeho náhled má spiše umožnit odpovídající výzkum procesů, jež se na vzniku této obrovské variability podílely. Jeho primárním cílem je tedy prosadit přijetí takové terminologie, která by tyto procesy postihovala a zároveň se vyhnula nedostatkům spojeným s použitím termínů ,rasa“ a „poddruh" u lidí:

Samožrejmě existují rozdíly, ale my chceme termín, kterým by bylo existenci takovýchto rozdílů možné popsat. Nechceme předpojatý termín, který rozdílům přidává významy, jež v nich nejsou obsaženy. Chceme termín, který odráží situaci tak přesně, jak je to jen možné, nikoliv takový, který celý problém překrucuje a zatemňuje (1962: 919).

Omezení postihující výzkum zákonitostí lidské variability není pouze terminologické; mnohem spíše se jedná o omezení konceptuální. Montaguova kritika rasy, již označil za Nejnebezpečnějš́ lidský mýtus (1942a, 1997), nespočívala jen v odsouzení chybného použití rasové teorie, ale selhání konceptu jako takového. Montaguovým největším úspěchem v tomto směru bylo nejen podrobné zpracování „dlouhé a trýznivé historie“ (Montagu 1962: 920) konceptu rasy; jeho terminologická dekonstrukce byla pokusem poskytnout nový konceptuální prostor pro studium lidské variability.

Termín „rasa“ považuje za samozřejmé to, co by ve skutečnosti mělo být předmětem zkoumání. A přesně tento fakt je zdůrazňován, použijete-li neutrální výraz „etnická skupina“. Jeho užití podněcuje $\mathrm{k}$ přechodu od neznalé a zmatené jistoty k přemýšlivé nejistotě. Pro laika stejně jako pro ostatní uzavírá termín „rasa“ dveře porozumění. Sousloví „etnická skupina“ je otevírá nebo je přinejmenším nechává pootevřené (1962: 926).

Termín „etnická skupina“ se zabývá otázkami, termín „rasa“ odpověd’mi, mylnými odpověd’mi, v nichž jsou většinou obsaženy pouze problémy vyžadující řešení ještě dříve, než může být dána jakákoliv správná odpověd' (1962: 927).

Montagu ve skutečnosti (1945) zaútočil na zneuživání systematické terminologie při zkoumání vývoje člověka daleko dříve, zejména ve spojitosti s termíny „primitivní“, „vyspělý“, „specializovaný““ a ,atavismus“.

Přestože Montaguovy neustálé kritické připomínky byly jasně zaměřené a erudované, mnoho kolegů jeho postoj velmi kritizovalo. Obecná debata o konceptu rasy byla zvlášt’ 
ostrá mezi Montaguem a Carletonem Coonem a také Hootonem (Marks 2000, viz také Dobzhansky a kol. 1963). Mnozí z těch, kteří připouštěli, že koncept rasy je neadekvátní, zaujímali stejně kritický postoj k pojmu etnicity, navrženému Montaguem; to platí zejména o Bracem (1964b). Kde Montagu tvrdil, že fyzičtí antropologové musí porozumět vlivu, jaký kultura na biologii má, Martin (1963) oponoval, že doménou fyzických antropologů je biologie zabývající se „fyzickými či genetickými“ rozdíly, aniž by brala v potaz kulturní sféru. Na tuto kritiku Montagu (1963: 1352) odpověděl: „Tytéž důvody, kvůli nimž je on proti používání tohoto termínu, ho pro mě činí přitažlivým.“

Montaguovo užívání „etnicity“ vedlo Martina k přesvědčení, že Montagu chápe koncept rasy špatně a že termín ,populace“ by byl možná lepší alternativou k výrazu „rasa“:

Je zklamáním, že Montagu nediskutoval př́mo termín „populace“. Jedná se o termín v současné literatuře obecně rozšířený, který dokonce sám Montagu často používá. „Populace“ odkazuje k tomu, že dochází ke kř́žžení jedinců nebo skupin provázenému různou mírou genetické výměny. Je to nesporně obecný a nepřesný termín, ale díky jeho nespecifičnosti s ním nejsou spojeny žádné implicitní představy a jediná bariéra, kterou představuje, se týká genetické výměny. Je pružný, a přesto smysluplný, takže se hodí k téměř jakémukoliv zkoumání fyzických charakteristik (1963: 403).

Montagư̊v biokulturní prŕístup není z jazykového hlediska příliš odlišný od vágní a nespecifické terminologie navrhované Martinem, Montagu však přesto trvá na tom, že každý nový koncept nebo termín reflektuje touhu vysvětlit mechanismy podílející se na fyzické diferenciaci:

Procesy fyzické (genetické) a kulturní evoluce se vzájemně nevylučují. A protože člověk se stal člověkem zejména proto, že se na fyzické prostředí adaptoval především prostřednictvím kultury, doufám, že žádní studenti fyzické antropologie nebudou již nikdy natolik pomýlení, aby se domnívali, že je možné rozumně zkoumat „fyzické nebo genetické“ rozdíly bez jakékoliv spojitosti s kulturou. Kulturní podtext je př́ítomný prakticky neustále (1963: 1352-3).

Toto pojetí biologie člověka jako esenciálně kulturní zůstává kontroverzní a samotný koncept kultury je při argumentaci namířené proti klasifikaci ras a poddruhů poněkud problematický. Kvůli této kontroverzi byl Montagu velmi ostře kritizován, dokonce i z řad svých spojenců v tažení proti konceptu rasy, kteří zastávali názor, že fyzická antropologie by se měla zabývat především genetickými důkazy.

Jak Polgar (1964), tak Brace (1964b) se domnívali, že Montagư̊v koncept etnicity s jeho záměrnou nejasností je prakticky k nerozeznání od konceptu rasy, a proto by neměl být uznán jako jeho ospravedlnitelná náhrada. Následkem toho Brace (1964b: 313) tvrdí, že podobné koncepce, s nimiž přišli tací jako Deniker, Huxley a Haddon a Montagu, nevedly k velkému pokroku v porozumění lidské variabilitě a diverzitě, nebot' nepředstavují alternativní přístup. Polgar (1964: 424) si myslí, že při používání konceptu rasy by se měl vysvětlit kontext, a nastiňuje tři operační definice: populace (geografické skupiny), kulturní skupiny nebo komunity a perceptuální soubory (založené na laické klasifikaci fenotypických znaků). Dochází k závěru, že studiu fylogenetických vztahů mezi geograficky, geneticky či morfologicky vymezenými skupinami by lépe posloužilo používání termínů ,populační shluky“ či „fylopopulace“. Brace (1964b) je však zásadně proti termínu „populace“, který, jak 
se domnívá, příliš opomíjí souvztažné kliny ${ }^{7}$ určitého znaku a selektivní síly. Na to Huxley odpovídá kritikou:

Rozhodně nepochybuji o tom, že se druh Homo ve svém raném vývoji začal dělit na geografické poddruhy a ty že se poměrně výrazně diferencovaly jeden od druhého, což vedlo ke vzniku takzvaných prvotních ras. Hranice mezi nimi byly od té doby samozřejmě rozostřeny migrací a křížením, ale základní diferenční znaky zůstávají stejné („Comments“ in Brace 1964b: 316).

Středem Huxleyho zájmu bylo formování lokálních skupin v rámci těchto „populací““. Právě v souvislosti s těmito menšími lokálními poddruhy nebo rasami tvrdí: „Neutrální termín ,etnická skupina“ se zdá být z vědeckého hlediska nejlepším označením“ („Comments“ in Brace 1964b: 316). Jasně se tak ukazuje, že rozdílné náhledy jsou dány úrovní analýzy.

Ačkoliv se Braceovy argumenty nezaměřují pouze na zkoumání základních nedostatků rasové taxonomie, ale také na nedostatky „etnicity“ nebo „populace“ jako náhradních termínů či konceptů, nepodařilo se mu nabídnout řešení uvedených problémů. $Z$ této debaty by mělo být jasné, že se jedná výhradně o sémantický argument, přičemž genetické principy, na nichž je založen, jsou naprosto přehlíženy nebo opomíjeny. Coon na Braceovy komentáře odpovídá: „Z Braceovy argumentace se zdá, jako by koncept rasy byl u člověka jedinečný a otázka existence ras by mohla být rozhodnuta pouze u lidí“ („Comments“ in Brace 1964b: 314). Count, také v odkazu na Bracea, jasně prohlašuje:

Člověk je účastníkem naprosto stejných evolučních procesů jako jiní živočichové - a žádných jiných. Pokud se kulturní rozvoj nazývá evolucí ve stejném slova smyslu jako organická evoluce, jedná se o logický zmatek. Pak je jednoduché tvrdit, že kultura ruší proces „,př́rodního výběru“. Nikdy jsem se nesetkal s dostatečným důkazem, který by takové tvrzení podpořil, a pouze zázraky mohou zrušit působení prírodního zákona („Comments“ in Brace 1964b: 315).

Tyto argumenty dokazují inherentní zaujatost ve prospěch biologie jakožto reflexe základního ,přírodního“ systému či struktury, přinejmenším v tomto konkrétním historickém momentu. Coon ani Count nepředkládají přesvědčivá vysvětlení, proč kultura nemůže nebo by neměla být považována za externí faktor, jehož působení má biologické dopady.

Montagu („Comment“ in Brace 1964b: 317) se pokoušel objasnit skutečnost, že etnicita je vlastně možným alternativním pojetím, a to nejen jako náhrada za slovo „rasa“ v antropologickém slovníku, ale proto, že podle jeho názoru nemohou být biologické a environmentální síly zkoumány jako izolované faktory, ale měly by být považovány za propojená kauzální vysvětlení. Montagu proto tvrdí, že etnicita představuje nový způsob konceptualizace lidské variability, nebot' věří, že sociální prostředí má prokazatelné dopady na biologické evoluční vzorce. Montagu jasně trval na tomto názoru:

7 „Klinu lze v zásadě chápat jako gradient znaku podél myšleného transektu např́ic hybridní zónou (hybridní zóna je definována jako oblast, ve které se dvě geneticky odlišné populace setkávají, křiží a dávají vznik alespoň nějakému hybridnímu potomstvu).“ (citováno z e-mailové komunikace s doc. RNDr. Milošem Macholánem, CSc.) (pozn. překl.) 
Opakovaně jsem zdůrazňoval smutný omyl, redukcionistický nedostatek, jímž je chápání populací lidských bytostí jako biologických ras z čistě zoologického hlediska, a to z toho jednoduchého důvodu, že lidské populace se nikdy jako „čistě zoologické“ taxony nechovaly.

Lidské populace se chovaly jedinečným kulturním zpo̊sobem, který dal vzniknout amalgámu variability genetických, morfologických a kulturních znaků, jenž vyžaduje daleko hlubší a důkladnější formy výzkumu než jednoduché „škatulkování" prostřednictvím klasifikace „ras“ („Comments“ in Brace 1964b: 317).

Přestože byl Montagu ve své argumentaci zdůvodňující jeho odmítnutí tradičního biologického př́istupu a přihlášení se k biokulturní perspektivě poměrně explicitní, mnoho jeho kritiků (viz například Brace 1964b, Count 1951, Garn 1961) se domnívá, že jeho důvody jsou sociologické a nejsou biologicky podložené. Na tyto námitky Montagu rozhodně odpovídá:

Samozřejmě jsem se zajímal o sociální a biologické důsledky zneužívání pojmu rasa mimo jiné i z humanitárních důvodů. Ale co mě zvlášt' znepokojovalo, byla nejasnost v používání tohoto konceptu fyzickými antropology. Nezdálo se mi, že by umělé skupiny nazývané většinou fyzických antropologů rasami odpovídaly realitě, která jim byla přisuzována. Kritizoval jsem ortodoxní antropologickou koncepci rasy z vědeckého, nikoliv humanitárního či sociologického hlediska. Z podobných důvodů považuje koncept rasy za nevyhovující rostoucí počet fyzických antropologů a biologů (Montagu 1964: 326).

Přestože byl biokulturní koncept etnicity rozpracován a doporučován některými nejváženějšími antropology své doby, Denikerem, Huxleym, Haddonem a Montaguem, došlo jen $\mathrm{k}$ malému pokroku $\mathrm{v}$ pochopení přínosu takového př́istupu. Montagu, který byl jedním z nejplodnějších antropologických pisatelů 20. století v oblasti biologické i kulturní antropologie, posunul biokulturní přístup dále než kdokoliv jiný. Brace („Foreword“ k Montagu 1997: 16) naznačuje, že zatímco Montagu chápal hloubku problémů na teoretické rovině, úplná škála základních biologických dat potřebných na podporu jeho teorií nebyla nikdy shromážděna. Při nedostatku podobných dat, jak tomu často bývá, přetrvávají jednoduchá vysvětlení, nebot' chybí kauzální vysvětlení komplexních faktorů. A přesně k tomu došlo v souvislosti s otázkou rasy a poddruhu. Biokulturní př́stupy zůstávají až na pár vzácných výjimek všeobecně přehlíženy nebo zkreslovány.

Možná nejlepším př́ikladem takové výjimky je sympozium Eugenické společnosti konané v Londýně v roce 1968 pod názvem „Biosociální aspekty rasy“ (Harrison a Peel 1969). ${ }^{8}$ V souvislosti s naší diskuzí jsou zvlášt’ zajímavé příspěvky Hulse (1969) a programové prohlášení (Galtonská přednáška) Harrisona (1969).

Hulse (1969: 31), Hootonův student, cituje časté rčení svého učitele a školitele: „Při setkání lidí dochází někdy k boji, ale vždycky k páření“. Přestože Hooton zůstal věrný rasovému pojetí biologie člověka, tento jeho názor je typický pro biokulturní přístup, podle nějž jsou izolované či z genetického hlediska uzavřené ,populace“ vzácné, pokud vůbec existují, nebot' míšení genů bylo po celou historii člověka obecným pravidlem. Pokud ony izolované

8 V kontextu etnicity existuje, jak se zdá, jen malý rozdíl mezi termíny „biosociální” a „biokulturní, nebot' tu dochází k zapojení sociálních, kulturních i biologických procesů. Oba termíny je tedy možné zaměňovat. 
skupiny existují, pak ve specifickém lokálním prostředí a nemohou být zařazeny do obecných rasových kategorií. Právě v této perspektivě se Hulse odklání od Hootonova trvání na fenotypu jakožto základu klasifikace. $Z$ argumentační pozice, jež se zdá být daleko bližší Boasově perspektivě, zpochybňuje Hulse znaky, které byly použivány jeho kolegy a předchůdci na podporu existence rasových skupin:

Znaky, jež jsou jasně kulturní svým původem a způsobem předávání, byly nepředloženě přičítány rase. Znaky, jež jsou prokazatelně tvárné a mění se vlivem prostředí, byly váženými vědci zařazeny mezi rasové charakteristiky. A aby to bylo ještě složitějšśi, často zjišt'ujeme, že některé znaky - dobrým př́kladem je tělesná výška - jsou sice možná $\mathrm{z}$ velké části ovlivněny genetikou, ale přesto se značně mění v důsledku prostředí (1969: 32).

I když Hulse ve svém pojednání nezmiňuje předchozí Montaguovu práci, jeho definice etnických skupin jako přizpůsobivých či proměnlivých sociokulturních jednotek sjednocených porozuměním a tradicí se jí nápadně podobá.

Termín „populace“ navržený Martinem jako náhrada za „rasu“ je pro Hulse také problematický. Hulse se domnívá, že lidské skupiny jsou odlišné od obecných biologických populací:

Geneticky vymezitelná reprodukční populace je naprosto jinou jednotkou, nebot' může být popsána biologickým způsobem. Kasty a etnické skupiny je možné najít jen u lidského druhu, ale reprodukční populace existují u většiny, ne-li u všech dvoupohlavních živočišných druhů. Bariéry mezi kastami a etnickými skupinami jsou důsledkem lidské kultury a představivosti. Bariéry mezi reprodukčními populacemi mohou být tvořeny oceány, horami, pouštěmi nebo také klimatickými pásmy... V mnoha př́padech, alespoň u lidského druhu, mohou mít společenská pravidla významný vliv na zachovávání genetických rozdílů; je však mnohem nepravděpodobnější, že by společenská pravidla vedla k jejich vzniku (1969: 33).

Hulse se zde blíží pojetí Huxleyho a Haddona, když tvrdí, že se fyzické charakteristiky hypotetických prvotních ras vyvinuly $\mathrm{v}$ důsledku specifických podnětů z okolí, ale rozšíření nebo zachování těchto charakteristik v rámci jednotlivých skupin či mezi skupinami naprríč geografickým prostředím záleží nejen na geografických překážkách v širším smyslu, ale také na společenských bariérách na lokální úrovni. Ve vztahu k fyzickému prostředí Hulse konkrétně naznačuje:

Genetické charakteristiky populace se zpravidla vyvinuly vlivem tlaku prostředí. Podle všeho vycházely z potřeby adaptace; adaptace na celek sociálního prostředí, nejen na jeho sociální aspekty. Proto následně zjištujeme, že se u lidských reprodukčních populací, jejichž předkové žili po tisíce let na různých částech planety, vyvinuly různé zvláštnosti (1969: 34).

Hulse proto předpokládá, že sociální a geografické prostředí jsou navzájem propojené.

Naproti tomu Harrison (1969) se rozhodl, že se bude - prizmatem biokulturního př́istupu - zajímat spíš o to, jak fyzičtí antropologové přistupují ke studiu takovéto variability znaků, přičemž zjistil, že se morfologické výzkumy úzce zaměrují na formu spíše než na funkci, čímž přehlíží související biologické procesy a jejich explanační význam: 
Většina znaků zkoumaných ranými fyzickými antropology - jasně viditelné morfologické znaky - není bezprostředně ovlivněna působením genů a variabilita těchto znaků je obvykle alespoň zčásti dána přímo variabilitou prostředí působící na jejich růst a rozvoj (Harrison 1969: 129-30).

Prvořadou doménou fyzických antropologů odchovaných Hootonem nebo jeho následovníky byla morfologická variabilita a její důsledky pro taxonomii, přestože sám Hooton se zajímal o genetickou dědičnost a eugeniku. Taková morfologická perspektiva je však založena pouze na analogii ${ }^{9}$ a nemusí být důkazem skutečného evolučního vztahu (Billinger 2006, Lewontin 1991). Nedostatek zájmu o tyto problémy vedl k předpokladu, že morfologie je př́mým dokladem genetických vzorců. Podle Harrisona „měli někteří fyzičtí antropologové stejně jako někteří genetici tendenci pohlížet na důsledky vlivu prostředí obecně téměř jako na nepř́ijemnost, která zastírá pravou povahu dědičné variability“ (1969: 131).

Podle Harrisona (1969: 132) je zájem antropologů výhradně o genetické důkazy při zkoumání dědičné variability problematický hlavně proto, že genetické znaky, na něž se soustředí, jako jsou systémy krevních skupin, struktura hemoglobinu, proteiny séra, krevní enzymy apod., považují prostě za dědičné, ale jejich genetický základ je v mnoha př́padech komplexnější. Takovéto polymorfní systémy se odlišují spíše četností genů než jejich přítomností či nepřítomností, a tak je při výzkumu populací zásadní rozlišovat mezi monomorfními a polymorfními znaky, nebot' určitý znak může být u některých populací monomorfní, zatímco u jiných polymorfní. Je však nesmírně vzácné, aby jedna populace měla monomorfně podmíněnou jednu variantu nějakého znaku, zatímco ostatní populace měly monomorfně podmíněnou jinou variantu téhož znaku. Klasifikace založené na takovýchto znacích jsou proto obzvlášt' problematické, nebot' míra variability těchto znaků v jednotlivých populacích je obvykle poměrně vysoká.

Harrison se zabývá geografickou variabilitou znaků, přičemž používá variabilitu tzv. kliny, což je koncept, který zavedl Huxley $(1938,1939)$ a který vysvětluje postupnou změnu měřených hodnot znaku (fenotypického, genetického, behaviorálního apod.) v prostoru. ${ }^{10}$ Podle Harrisona (1969: 132) mají změny v četnosti genů a množství znaků (průměrné hodnoty) tendenci $\mathrm{k}$ plynulému a rovnoměrnému výskytu, přestože mohou existovat př́ípady, kdy jsou změny poměrně rychlé. Pravidelnosti v četnosti genů (kliny genů) a kvantitativních znaků (kliny fenotypů) nemusí být nutně stejné; předpoklad, že geografická klina fyzických znaků vypovídá o změně četnosti genů, může být proto přinejmenším nepřesný. To vede Harrisona k závěru:

Klinální charakter variability a nesoulad v rozšíření [genetických a fenotypických, pozn. překl.] znaků vedou k tomu, že jakýkoliv klasifikační systém geografické variability je nejen arbitrární, ale také umělý. Livingstone (1962) došel až tak daleko, že tvrdil, že neexistují rasy, ale pouze kliny. To se mi jeví jako příliš extrémní postoj. Jak už bylo řečeno, rasy jsou přijatelně definovány biologií

9 „Analogie je funkční a tvarová shoda některých ústrojů lišících se původem, např. kř́idel hmyzu a ptákư“ (citováno z Klimeš, Lumír. 1981. Slovník cizích slov. Praha. Státní pedagogické nakladatelství.) (pozn. překl.)

10 Koncept kliny zmiňuje také Brace (1964a, 1964b); Livingstone (1962) trval na tom, že lidská variabilita je klinální spíše než rasová. 
jako populace, jež se liší četností genů, a jelikož takové populace bezesporu existují, musí existovat i rasy (1969: 140-1).

Tato pozice je matoucí, nebot' Harrison tvrdí, že rasy existují, ale jejich klasifikace je arbitrární a umělá.

Přestože Harrison narozdíl od Hulse nedůvěřuje etnické klasifikaci, považuje rasovou klasifikaci lidí za zásadně odlišnou od jiných druhů:

Je možné učinit závěr, že koncept rasy není pro vědecký výzkum člověka př́liš přínosný; chybí mu přesnost a sám o sobě nic nevysvětluje. Dokonce ani názvy ras - např́íklad mongoloidní, negroidní, kavkazská - nejsou přesné, přestože slouží jako předpřipravené a přibližné shrnutí množství fyzických znaků, jež se u některých populací obvykle vyskytují. Podle mého osobního názoru je však z vědeckého a etického hlediska chybou, aby biologové studující člověka popírali existenci rasy. Množství geografických variant genetických systémů je obrovské, nebot' i přes klinální charakter této variability dochází ke skokovým změnám. Rasy zjevně existují a domnívám se, že nazývat je etnickými skupinami nepřináší nic užitečného. Důležité je to, že biologická variabilita, o níž jsem pojednával a jež je základem konceptu rasy, nám neříká nic o povaze a variabilitě jiných lidských vlastností (1969: 141).

Ačkoli Harrison jednoznačně odmítá koncept etnicity a problematizuje používání „rasy“, přičemž však zdánlivě v rozporu s tím vyzdvihuje její význam, zdá se, že jeho pohled na lidskou variabilitu se liší od pojetí Denikerova, Huxleyho a Haddonova, Montaguova a Hulseova pouze setrváváním u tradiční terminologie. Rozdílná je však Harrisonova představa, že lidská variabilita musí zapadat do tradičního biologického (nebo prírodně historického) schématu.

\section{Tvoří etnické skupiny samostatné biologické jednotky?}

O biologických důsledcích etnicity psali v nedávné době Crews a Bindon (1991), Corcos (1997) a Molnar (2002), ale pouze zběžně. Důkladnější pojednání o otázce rasy a etnicity z filozofické perspektivy však nabízí Kitcher (2003), přičemž tvrdí, že antropologové, kteří odmítají koncept rasy, zakládají své úvahy na dvou hlavních bodech: (1) fenotypické znaky nepředstavují esenciální hodnotu ani nezakládají př́icinný vztah s jinými znaky, které by měly status esenciální hodnoty, (2) z hlediska genotypu jsou rozdíly uvnitř jedné rasy daleko výraznější než mezi rasami. Kitcher nevyjadřuje nesouhlas ani s jedním z těchto bodů, ale nevěří, že postačují k odmítnutí konceptu rasy. Naznačuje spíš, že autorům, kteří koncept rasy odmítají, se nepodařilo rozpoznat méně zjevné oblasti, v nichž může mít rasové rozdělení biologický význam (Kitcher 2003: 232). Kitcher (2003: 234) se zaměřuje na vzájemné vztahy mezi rasou, etnicitou, biologií a kulturou a zkoumá způsoby, jimiž by bylo možné koncept rasy dále rozvíjet tak, aby odpovídal současnému chápání lidské variability. Také se ptá, jaké důsledky by mohlo mít nahrazení biologického konceptu rasy sociálním konceptem etnicity.

Kitcher (2003: 234) nastiňuje tři nezbytné podmínky, jež by podle něj měl jakýkoliv koncept rasy splňovat: 
(R1) Rasové rozdělení se skládá ze souboru podsouborů druhu Homo sapiens. Tyto podsoubory jsou čistými rasami. Jedinci, kteří nepatří k žádné čisté rase, mají smíšenou rasu.

(R2) At’ je rasové rozdělení jakékoliv, čisté rasy jsou uzavřené z hlediska reprodukce. To znamená, že potomci rodičů, jež oba náleží k rase $\mathrm{R}$, mají také rasu $\mathrm{R}$.

(R3) At' je rasové rozdělení jakékoliv, všichni předci jakéhokoliv příslušníka čisté rasy patří $\mathrm{k}$ téže rase. Rodiče jedince rasy $\mathrm{R}$ mají rasu $\mathrm{R}$.

Zásadním tvrzením, které chce Kitcher (2003: 236) dokázat, je, že „Koncept rasy je historickým konceptem “ a jako takový spočívá na ideji populace, jež je dlouhodobě více či méně oddělená od ostatních z důvodu převažujících praktik příbuzenského křížení a navazování endogamních vztahů. Kitcher dále vysvětluje, že pojem reprodukční izolace je obvykle špatně chápán, nebot' izolace nemusí být absolutní a hybridní zóny u ostatních druhů skýtají radu př́kladi̊ toho, že mezi dvěma a více jasně oddělenými populacemi může docházet v omezené míře ke křrižení. Kitcher v tomto ohledu ř́ká:

Pokud by existovala funkční biologická koncepce rasy, pak by musela, jak se domnívám, respektovat podmínky (R1)-(R3), používat tuto historickou konstrukci ve významu zakladatelských populací $\mathrm{a}$,inbredních“ linií11 a konečně vyžadovat, aby v případě kontaktu mezi rasami byl rozdíl mezi pravděpodobností výběru partnera v rámci rasy a mimo ni dostatečně velký, aby se zachovaly rozdílné znaky, jimiž se rasy od sebe odlišují (které musí být patrně alespoň zčásti fenotypické, nebot' organismy nemají prímý přístup k vlastním genům) (2003: 238).

Kitcherův koncept rasy se tedy opírá o pojetí alespoň zhruba izolovaných reprodukčních populací, u nichž přetrvává podobnost odlišujících fyzických znaků. Na základě dat z amerického sčítání lidu z roku 1970 a z množství výzkumů týkajících se rasově smíšených a homogenních manželství se Kitcher pokusil empiricky dokázat, že u lidí existují zákonitosti reprodukce $\mathrm{v}$ podstatě odpovídající jeho představě izolovaných reprodukčních populací a směřující k zachovávání fenotypických rozdílů, které vznikly u geograficky oddělených zakladatelských populací.

Problém Kitcherových závěrů tkví zcela zjevně v datech, která používá k podpoře svého tvrzení, že malý počet manželství uzavíraných napříč některými americkými populacemi, zejména afroamerickou a bělošskou, nasvědčuje tomu, že tyto populace se z evoluční (a možná také ekologické) perspektivy chovají jako oddělené jednotky. Spolehlivost dat z doby před více než 30 lety je však s rostoucí globalizací přinejmenším omezená. Aby byly tyto argumenty přesvědčivé, bylo by zapotřebí dokázat, že výběr partnerů vlastní rasy je dlouhodobým historickým trendem.

Údaje z kanadského sčítání lidu z roku 2001 ukazují několik zajímavých trendů týkajících se „smíšených svazkư“ (Milan a Hamm 2004), jež jsou - tedy alespoň v kanadském kontextu - v rozporu s Kitcherovou hypotézou o výběru partnerů výlučně v rámci ras. $\mathrm{V}$ roce 2001 představovaly smíšené svazky v Kanadě 3,2 procenta ze všech lidí žijících v páru (týká

11 Inbrední linie zahrnuje jedince se stejným genotypem. Tato linie je výsledkem úzkého kř̌́žení mezi př́buznými jedinci (pozn. překl.). 
se právně uzavřených i faktických manželství), zatímco ve Spojených státech to v roce 2000 byla 2 procenta. Tyto smíšené svazky jsou tvořeny př́slušníkem jedné „viditelné“ menšiny a př́slušníkem jedné „neviditelné“ menšiny nebo příslušníky dvou různých „viditelných“ menšin. ${ }^{12}$ Přestože se to může zdát vzhledem k celkovému počtu svazků málo, jedná se o 35procentní nárůst oproti sčítání z roku 1991. Smíšené svazky se nejčastěji vyskytovaly mezi prŕslušníky „viditelné“ a „,neviditelné“ menšiny (tj. bělochy) - v roce 2001 tvořily 2,8 procent ze všech párů, což představuje zvýšení oproti hodnotě 2,4 procent z roku 1991. Pro smíšené svazky mezi obyvatelstvem černošského a bělošského typu neexistují data, ale 57 procent černochů (Afričanů nebo Afroameričanů) mělo za partnera jiného černocha a zbývajících 43 procent žilo ve smíšených svazcích. V protikladu ke Kitcherovým zjištěním byl v roce 2001 v Kanadě nejvyšší absolutní počet smíšených párů, v nichž byl jedním z partnerů černoch. Data ze sčítání lidu 2001 také ukazují, že podíl smíšených svazků se neliší v závislosti na rasové skupině, ale na etnické skupině (Tabulka 2) a je ovlivněn věkem, lokalitou, vzděláním a místem narození (Tabulka 3). ${ }^{13}$

Tabulka 2: Podíl smíšených párů podle údajů z kanadského sčítání lidu z roku 2001 (převzato z Milan a Hamm 2004: 3)

\begin{tabular}{|l|c|c|c|}
\hline Vybraná „viditelná“ menšina & Celkový počet párů & $\begin{array}{c}\text { Partneři ze stejné } \\
\text { "viditelné“ menšiny (\%) }\end{array}$ & Smĩ̃ené svazky (\%) \\
\hline Japonci & 25100 & 30 & 70 \\
\hline Latinoameričané & 57800 & 55 & 45 \\
\hline Černoši & 117800 & 57 & 43 \\
\hline Filipínci & 78700 & 67 & 33 \\
\hline Jihovýchodní Asiaté & 45200 & 74 & 26 \\
\hline Arabové/Západní Asiaté & 73800 & 76 & 24 \\
\hline Korejci & 24800 & 82 & 18 \\
\hline Číňané & 26500 & 84 & 16 \\
\hline Jižní Asiaté & 232000 & 87 & 13 \\
\hline
\end{tabular}

12 V kanadském zákoně o rovném zacházení v zaměstnání (Employment Equity Act) jsou viditelné menšiny definované jako „lidé, kromě domorodého obyvatelstva, kteří nejsou bělošské rasy nebo nemají bílou barvu pleti““ (Milan a Hamm 2004: 2).

13 Data ze sčítání lidu z roku 2001 také ukazují, že: (a) u Japonců je podíl smíšených svazků vyšší, ale jsou nejmenší minoritní skupinou, zatímco Číňané a další Jihoasiaté sice tvoří největší menšiny, ale podíl smíšených párů je u nich nejnižší; (b) smíšené svazky se nejčastěji vyskytují u mladých lidí žijících ve městech; (c) lidé žijící ve smíšených svazcích mají spíše vyšší vzdělání a narodili se v cizině; (d) smíšené páry žijí častěji ve faktickém manželství než v právně uznaném manželství (Milan a Hamm 2004). 
Tabulka 3: Faktory ovlivňující smîsené svazky podle údajů kanadského sčítání lidu z roku 2001 (převzato z Milan a Hamm 2004: 5)

\begin{tabular}{|c|c|c|c|}
\hline & \multirow[t]{2}{*}{ Celkem } & \multicolumn{2}{|c|}{ Smišené svazky } \\
\hline & & $\begin{array}{l}\text { Př́slušníci dvou různých } \\
\text { „viditelných“ menšin (\%) }\end{array}$ & $\begin{array}{c}\text { Přislušník „,viditelné“ menšiny } \\
\text { a prǐslušník „,neviditelné“ } \\
\text { menšiny (\%) }\end{array}$ \\
\hline \multicolumn{4}{|l|}{ Věk } \\
\hline 15 a více & 3,2 & 0,4 & 2,8 \\
\hline $15-19$ & 5,4 & 0,7 & 4,6 \\
\hline $20-29$ & 5,3 & 0,6 & 4,6 \\
\hline $30-44$ & 4,3 & 0,6 & 3,8 \\
\hline $45-64$ & 2,5 & 0,3 & 2,2 \\
\hline 65 a více & 1,0 & 0,1 & 0,9 \\
\hline \multicolumn{4}{|l|}{ Vzdělání } \\
\hline Nižší než středoškolské & 1,5 & 0,2 & 1,3 \\
\hline Středoškolské & 2,3 & 0,3 & 2,0 \\
\hline $\begin{array}{l}\text { Vyšší než středoškolské } \\
\text { (s výjimkou univerzitního) }\end{array}$ & 3,6 & 0,5 & 3,1 \\
\hline Univerziłní & 5,6 & 0,7 & 5,0 \\
\hline \multicolumn{4}{|l|}{ Místo narození } \\
\hline Kanada & 2,1 & 0,1 & 2,0 \\
\hline Jiná zemè & 6,7 & 1,5 & 5,2 \\
\hline
\end{tabular}

Také Wilson (2004) kritizoval Kitcherovo použití těchto dat a jeho hypotézy týkající se reprodukční izolace, nebot' charakter rasové sebeidentifikace a rasové klasifikace se v datech ze sčítání lidu neustále mění a existuje tendence směšovat historické, biologické, kulturní a etnické kategorie. Proto také dochází k posunu přibližných zákonitostí izolace, jež jsou i podle Kitchera proměnlivé, čímž ovšem nemohou být považovány za „reálný” př́iklad toho, co chtěl dokázat. Kitcher přesto na základě uvedených dat dedukuje, že:

Můžeme říci, že rasy jsou jak sociální konstrukcí, tak biologickou skutečností. Biologická realita do nich proniká skrze objektivně existující zákonitosti reprodukce, přesněji řečeno prostřednictvím zjevného sklonu vybírat si partnery mezi ostatními „černochy” (respektive mezi ostatními „,bělochy”); sociální konstrukce spočívá ve skutečnosti, že tyto sklony mají složité společenské příčiny (2003: 247).

Zjištění, že koncept může být jak sociálním konstruktem, tak biologickou skutečností nemělo být pro Kitchera překvapením, nebot' tato idea byla o několik let dříve poměrně výmluvně vyložena Hackingem (1999). Kitcher tvrdí, že tato interakce mezi sociálním a biologickým je příčinou velkého rozdílu mezi pravděpodobností výběru partnera v rámci vlastní rasy a mimo ni, který vede k zachovávání fenotypických a genetických vlastností př́itomných u zakladatelských populací. Domnívá se tedy, že takovéto skupiny jsou z hlediska 
mikroevoluce oddělenými evolučními jednotkami, jež je možné klasifikovat jako rasy, přestože možná ne ve smyslu tradičních lidských rasových kategorií.

Mechanismy Kitcherova argumentu proti odmítání konceptu rasy zjevně fungují na dvou úrovních:

Zatímco z biologického hlediska může být koncept lidských ras smysluplný, protože existují rozdíly v četnosti genů, jež zřjejě kvưli nízké pravděpodobnosti výběru partnera mezi př́slušníky jiných ras nemizí, vysvětlení preference volby určitého partnera asi nelze opírat o žádné biologické charakteristiky. Rasa tak je zřejmě téměr doslova sociálně konstruovaná, nebot' naše způsoby akulturace vedou k zachovávání genetických odlišností různých rasových skupin (2003: 247).

Tento aspekt sociálního konstruování toho, co je považováno za „rasové” skupiny, byl jádrem pojetí etnicity prosazovaného Denikerem, Huxleym a Haddonem a zvláště Montaguem. Kitcher (2003: 248) však takovou variabilitu na etnické úrovni chápe jako paralelní s variabilitou biologickou:

(E1) Etnické rozdělení spočívá v rozdělení Homo sapiens do podsouborů, které se nepřekrývají. Tyto podsoubory jsou čistými etniky. Jedinci, kteří nepatří do žádného podsouboru, mají smíšenou etnicitu.

(E2) Čistá etnika jsou uzavřena z hlediska kulturního přenosu. To znamená, že kulturní „potomci” „rodičů” s etnicitou E mají také etnicitu E.

(E3) Všichni kulturní „předci” jakéhokoliv př́slušníka čistého etnika mají/měli tutéž etnicitu jako on. Pokud má někdo etnicitu E, pak všichni jeho kulturní „rodiče” mají/měli také etnicitu E.

Tato podobnost je poněkud pochybná, nebot' Kitcherův důraz na čistotu jak na biologické, tak na sociální úrovni se zdá být nerealistický, a to i ve světle jeho relativistického přístupu ke genetické a kulturní výměně nahlížené jako přibližně izolované.

Kitcherova víra v implicitní vztah mezi biologií a kulturou ho vede k závěru, že existuje proces neustálé harmonizace a posilování tohoto vztahu:

Na biologické úrovni je kř̌́žení mezi rasami omezeno rozdíly v kultuře, kterou si příslušníci různých ras osvojili. Na kulturní úrovni zůstávají kulturní vzorce zachovány, nebot' kultura bývá obvykle předávána především rodiči a jinými členy rodiny (kteří mohou ovlivnit také ochotu přijmout jiné potenciální kulturní rodiče), kteří patří ke stejné rase a sdílí tutéž etnicitu. Specifickým důsledkem... je, že rasismus minulosti formuje dnešní postoje lidí - zvláště jejich postoje k sexuálním svazkům - a že tato skutečnost může vést $\mathrm{k}$ trvalému upřednostňování vlastní skupiny při výběru partnera (2003: 249).

Zdá se, že Kitcher by měl poukazovat na něco zásadnějšího než je struktura společnosti a možné důsledky rasistického myšlení, i když je nutné připustit, že otevírá dveře perspektivě, podle níž lidé možná mají „hluboko zakotvený” sklon vybírat partnery výlučně v rámci svých skupin. Největším problémem jeho koncepce je možná to, že předpokládá implicitní spojení mezi biologií a kulturou a domnívá se, že existuje prŕmý vztah mezi rasou a etnicitou, ale už nepřipouští možnost, že rasa a etnicita jsou jedno a totéž. 
Rasová uskupení, o nichž Kitcher mluví, by ve smyslu Linného taxonomické hierarchie nebo jakéhokoliv systému sociální nebo biologické taxonomie lidských skupin mohla být také podrasami, př́buzenskými skupinami, varietami nebo jinými poddruhy (Wilson 2004: 9). Pokud je etnicita proměnlivým sociálním termínem, nemůže být v souladu se statickou biologickou koncepcí rasy. Jestliže takový vztah existuje, pak by etnicita musela být daleko spiše kauzálním faktorem (za nepřítomnosti geograficko-environmentálních bariér) a „rasová” skupina výsledkem. Jelikož je ale velmi nepravděpodobné, že by nějaká skupina byla zcela oddělená od ostatních, pojetí rasové kategorizace nedokáže vysvětlit žádný aspekt lidské variability. Pokud má rasové rozdělení společenské příčiny, pak se nejedná o rasy $\mathrm{v}$ biologickém slova smyslu. I kdyby tato situace existovala pouze u lidských populací, stačilo by to $\mathrm{k}$ tomu, abychom opustili pojetí rasy přinejmenším v souvislosti s moderním Homo sapiens.

Kitcherovy komentáře, podnětné v souvislosti s „hlubokým zakotvením” preferencí při výběru partnera, vedou k zajímavějším otázkám ohledně sociálních a biologických struktur, přestože se tím zároveň dostáváme na tenký led esencialismu. Vyhýbání se konceptu rasy při vysvětlování lidské variability by však bylo zbytečné, pokud by - bez ohledu na možnost či nemožnost dokázat existenci biologických ras - bylo možné dokázat, že lidská mysl bude vždy kategorizovat svět na základě předpokladu, že skupiny jsou výlučnými sociálními či biologickými entitami. Rasy by pak byly skutečností, alespoň v kognitivním smyslu. GilWhite (2001) shromáždil tvrzení o kognitivní roli lidských etnických kategorií, které značně přesahují kulturní chápání obecných kategorií „přirozeného druhu”, jejichž obhájci byli Atran (1990) a Hirschfeld (1996, 1998).

Atran ani Hirschfeld nepovažují rasu za vrozený koncept, ale spíš za výsledek interakce mezi kulturou a kognicí. Atran (1990: 49) se domnívá, že některé kognitivní procesy, jako je např́íklad klasifikace barev nebo kategorizace „živých druhư“ (living kinds), jsou jen minimálně ovlivňovány společenskými změnami, zatímco jiné formy kulturního vědění, např́ílad totemismus nebo molekulární biologie, jsou závislé na zvláštních kulturních institucích, jež zajišt'ují jejich existenci a předávání. Lidé tedy obvykle klasifikují živé druhy (living kinds) podle typu a zjevné morfologické odlišnosti mezi lidskými skupinami mohou být považovány za přirozené biologické variace, od nichž se odvíjí sociální hierarchizace (Atran 1990: 78). Hirschfeld (1996: 13) věří, že lidé zpravidla konceptualizují lidský svět jako složený z odlišných typů - označuje je jako „lidské druhy” (human kinds) -, jimž jsou přisuzovány společné vrozené nebo jiné podstatné znaky. Hirschfeld (1998) dokazuje, že i když je biologická variabilita lidí současným systémem rasové klasifikace zachycena pouze v omezené míře, systémy „přirozené” lidské taxonomie existují doslova v každé kultuře a dokonce i velmi malé děti tř́́í lidi nejraději podle rasy a genderu. Také však vysvětluje, že děti nevnímají rasy jako konstantní a že vývoj hluboce zakořeněného „přirozeného preferování určitého lidského druhu" je důsledkem manipulace přirozené kategorizace politickou ekonomií.

Gil-White (2001) posouvá tento kognitivní argument dál k esencialismu, když tvrdí, že lidé svým rozumem vytvářjí z etnických skupin druhy, což vychází z evoluční adaptace a z jejího diskriminačního účinku, který spočívá v podpoře vztahů v rámci vlastní skupiny a endogamie. Pokud by psychologie nebo filozofie dokázaly, že takováto perspektiva má nějakou významnější explanační sílu, měli bychom před sebou důležitou úvahu, na jejímž 
základě bychom mohli rozvinout debatu o biologickém charakteru etnicity. Pokud, jak GilWhite vysvětluje, ,je pravda, že etnika [etnické skupiny] naivně a intuitivně považujeme za druhy, zlepšilo by to pravděpodobně naše chápání toho, jak se etničtí aktéři chovají v různých kontextech“ (2001: 519). Jestliže navíc opravdu můžeme pochopit, jak lidská mysl vnímá ostatní na základě vztahů a fenotypů - což by na oplátku vysvětlilo strukturu lokálních komunit -, pak bychom mohli tvrdit, že koncept etnicity je z biologického hlediska smysluplný a představuje vhodný prostředek, pomocí něhož by bylo možné odklonit studium lidské variability od dominantní rasové epistemologie.

Gil-White (2001: 518) se s využitím Hirschfeldova pojetí „lidských druhů” (human kinds) zamýšlí nad tím, že upřednostňování nám podobných etnik je zásadním kognitivním procesem, který má zvláštní význam v procesu evoluční adaptace: „Informace o těchto ,druzích“ jsou důležité, nebot’ pokusy o interakce s cizinci, kteří mají odlišné normy chování, budou spíše selhávat než zakládat vzájemně výhodné vztahy." Gil-White (2001: 514) také naznačuje, že identifikace a hierarchizace přirozených lidských skupin mají za následek to, že jsou jim přisuzovány domnělé esenciální charakteristiky. A s těmito domnělými esenciálními charakteristikami přichází zaměňování etnické skupiny a rasy:

...esencializujeme rasy, nebot’ se mylně „domníváme”, že jsou etnickými skupinami. Vyhodnocujeme tedy „rasy” jako etnika, přestože nemohou ani v nejdivočejších představách představovat normu nebo jakékoliv behaviorální hranice, což byl původní důvod pro odmítnutí modelu živých druhů (living kind) (Gil-White 2001: 534).

Jakkoli mohou být tyto argumenty zajímavé, přece jsou v mnoha ohledech nedostatečné a nepřispívají významnějším způsobem k pochopení lidské biologie či psychologie více než práce Atrana a Hirschfelda, na nichž Gil-White svou argumentaci staví. Jeho prŕstup je spíše sociobiologický než biokulturní.

Celá premisa jeho tvrzení je zaprvé postavena na etnobiologické nauce, jež poukazuje na značné přesahy mezi tradičními a západními vědeckými modely biologické klasifikace. Je tu také zamlčený předpoklad, že druh je v biologii hlavní jednotkou, jelikož mnohé taxonomie kulturních skupin poměrně přesně odráží systematické taxonomie a koncept biologických druhů je založen na představě, že druhy jsou přirozeně výlučné reprodukční populace. Ve skutečnosti se sice předpokládá, že druhy představují výlučné reprodukční populace, ale dosud to nebylo přesvědčivě dokázáno. Zadruhé, pokud v mysli dochází k zaměňování „rasy” a „etnika” a etnika jsou chápána především jako druhy, neměly by být rasy logicky také považovány za druhy? Gil-Whiteova koncepce založená na rozdílnosti rasy a etnické skupiny je nejasná. Ale v tomto př́padě nemusíme mluvit o etnických skupinách, nebot' rasy kdysi byly reálnými biologickými entitami vymyšlenými lidským rozumem a vyprodukovanými sebe-domestikující reprodukcí. Zatřetí, předpoklad, že takovýto hypotetický kognitivní proces zaujímal v rámci evoluční adaptace významnou roli, je patrně mylný, jelikož exogamie je geneticky výhodnější než endogamie, nebot' přináší nové a příznivé biologické prvky prostřednictvím „efektu zakladatele“.

Pokud by Gil-Whiteovy teze byly správné, existovaly by zcela jasné biologické rasy, nikoliv etnické skupiny, nebot' by byly výlučnými a diskriminujícími reprodukčními populacemi. Jak víme, lidská mobilita a zvědavost vedly k rozsáhlému toku genů, jenž zrušil jakou- 
koliv rasovou „čistotu”, která možná někdy v průběhu lidské evoluce existovala. Tuto perspektivu zaujímají rovněž multiregionalisté, kteří se domnívají, že Homo sapiens se vyvinul z populace Homo erectus nezávisle na sobě v Africe, Asii a Evropě, přičemž však mezi všemi populacemi docházelo k jistému toku genů (viz Wolpoff a Caspari 1997, 2000). Proto je možná vhodnější používat Hirschfeldovu práci o kognici kategorizace, jež považuje klasifikaci za esenciální rozumový proces, který je zároveň flexibilní a ovlivňovaný silami politické ekonomie. Zdá se, že tyto kategorie představují něco velmi blízkého Denikerovu, Huxleyho a Haddonovu a Montaguovu pojetí etnických skupin, jež jsou flexibilní a historicky podmíněné, aniž by pozbývaly skutečný biologický význam.

\section{Závěr}

Tento článek poskytl především historiografický pohled na argumenty obhajující koncept etnicity nejen jako sociální kategorie, ale jako kategorie s reálným biologickým významem. Při tom bylo nezbytné podívat se více také na podhodnocenou literaturu volající po biokulturním př́stupu ke studiu lidské variability a zavrhující jednoduché taxonomie. Při přechodu $\mathrm{k}$ současným úvahám o etnicitě byla také kriticky zhodnocena filozofická a psychologická literatura pojednávající o esenciální povaze taxonomie druhů a poddruhů. Tento článek vyjadřuje požadavek po funkčním spiše než strukturálním př́istupu ke studiu biologie člověka, jenž musí být ve své podstatě biokulturní. Zákonitosti mají jen omezenou platnost, pokud chybí diskuze o procesech, jež je vytvořily. Lidé představují pro biologii jedinečný problém, nebot' kultura je evoluční adaptační strategií (narozdíl od tvrzení GilWhitea, že etnická klasifikace je adaptační strategií; viz Richerson a Boyd 2005). Harrison (1969) tvrdí, že zneplatnění konceptu rasy u lidí ze sociálních/kulturních důvodů nepovede nutně ke zrušení biologického konceptu rasy. To je rozhodně pravda, ale neznamená to, že by tento koncept nemohl nebo neměl být zrušen alespoň v př́padě člověka a zcela zjevně, pokud by mohl být zrušen ve vztahu $\mathrm{k}$ dalším druhům, pak by se přirozeně považoval za neplatný i u lidí. Už by mělo být jasné, že koncept rasy a koncept poddruhu nejsou problematické jen v obecném biologickém použití, ale že jsou bezmocné především pro výzkum lidské variability.

V tomto článku jsme také nahlédli, že termín „populace” se stal populární alternativou $\mathrm{k}$ rasové terminologii. Populace $\mathrm{v}$ mendelovském smyslu je definována jak mírou izolace (endogamie), tak i tokem genů (exogamie). V každém genofondu (populace) existují různé četnosti genů v závislosti na stupni jeho izolace. Molnar (2002: 55, 253), podobně jako Kitcher, definuje genofond jako skupinu vzájemně se reprodukujících jednotlivých organismů tvořících něco, co by mohlo být přesně nazváno reprodukčni populace nebo démy. Ty představují řadu reprodukčních kruhů relativně izolovaných od ostatních takových skupin. Tato izolace může samozřejmě vzniknout $\mathrm{v}$ důsledku různých typů bariér (např́klad fyzických, kulturních, sociálních, lingvistických apod.) a může být obecně chápána jako interakce mezi mnoha biologickými a behaviorálními silami. Znovu by mělo být zdůrazněno, že tento typ definice se jasně podobá konceptu etnicity, jenž byl podrobně popsán $\mathrm{v}$ tomto článku. Etnické skupiny jsou definovány jako historicky specifická omezení toku genů nebo obecná preference endogamie. Tato preference je pravděpodobně sociálně podmíněná nebo 
ekologická spíše než kognitivně esenciální. Kde však reprodukční populace dosahuje vysoké míry izolace, tam mohou být etnické skupiny otevřenými systémy.

Přestože lidé nežijí mimo biologický svět a mimo dosah evolučních sil, technologická kontrola fertility, zdraví a mortality s sebou nese potřebu vypořádat se s tvrzením, že moderní genetické struktury jsou ve většině světa ovlivněny spíše zákonitostmi ve výběru partnera a mobility než přírodním výběrem (Macbeth 1993: 49, 81). V takovém případě musí být lidská variabilita biokulturní. Někteří se domnívají, že „,populace” a „etnicita” získávají podobný význam, když se používají v biologickém smyslu (viz Crews a Bindon 1991: 45), avšak termín „populace” pouze zastupuje „rasu” (viz Caspari 2003: 73). Nejedná se o konceptuální, ale o terminologický posun. S termínem ,ppopulace” je svázán hierarchický aspekt rasy a poddruhu, přičemž pro etnickou biologii je problémem to, že populace představuje různé úrovně organizace a není příliš nápomocná při vytváření taxonomií. Montagửv pokus posunout biokulturní př́stup dopředu byl jistě omezený jeho neschopností poskytnout data dokazující, jaké by mohly různé typy biologických analýz ovlivnit taxonomii. Je však třeba si uvědomit, že k tomu, aby měl odpovídající sběr dat nějakou analytickou hodnotu, musí být pevně teoreticky zakotven.

Přeložila: Kateřina Dvořáková

\section{Literatura}

Atran, S. 1990. Cognitive Foundations of Natural History: Towards an Anthropology of Science. New York: Cambridge University Press.

Billinger, M. S. 2006. „Beyond the Racial Paradigm: New Perspectives on Human Biological Variation", PhD dissertation, Edmonton: University of Alberta, Department of Anthropology.

Boas, F. 1911. The Mind of Primitive Man. New York: Macmillan.

Boas, F. 1912. „Changes in the Bodily Form of Descendants of Immigrants.“ American Anthropologist, 14(3): 530-62.

Boas, F. 1940. Race, Language and Culture. New York: Macmillan.

Brace, C. L. 1964a. „A Nonracial Approach Towards the Understanding of Human Diversity.“ In A. Montagu (ed.) The Concept of Race, New York : Free Press, s. 103-152.

Brace, C. L. 1964b. „On the Race Concept.“ Current Antropology, vol. 5(4): 313-320.

Cann, R. L.; Stoneking, M.; Wilson, A. C. 1987. „Mitochondrial DNA and Human Evolution.“ Nature, 325: 31-36.

Caspari, R. 2003. „From Types to Populations: A Century of Race, Physical Anthropology, and the American Anthropological Association." American Anthropologist, 105(1): 65-76.

Collard, M.; Wood, B. 2000. „How Reliable are Human Phylogenetic Hypotheses?“ Proceedings of the National Academy of Science of the United States of America, 97(9): 5003-5006.

Corcos, A. F. 1997. The Myth of Human Races. East Lansing: Michigan State University Press.

Count, E. W. 1951. „Discussion of “A Consideration of the Concept of Race. In M.F. Ashley Montagu Cold Spring Harbor Symposia on Quantitative Biology. 15: 335. 
Crews, D. E.; Bindon, J. R. 1991. „Ethnicity as a Taxonomic Tool in Biomedical and Biosocial Research." Ethnicity and Disease, 1: 42-9.

Darwin, C. 1871. The Descent of Man and Selection in Relation to Sex. London: J. Murray.

Darwin, C. 1888. The Descent of Man, 2nd edn. London: J. Murray.

Deniker, J. 1904. The Races of Man: An Outline of Anthropology and Ethnography. London: Walter Scott Publishing Co.

Dobzhansky, T.; Montanu, A.; Coon, C.S. 1963. „Two Views of Coon’s Origin of Races with Comments by Coon and Replies." Current Antropology, 4(4): 360-367.

Garn, S.M. 1961. Human Races. Springfield, IL: C.C. Thomas.

Gil-White, F. J. 2001. „Are Ethnic Groups Biological "Species” to the Human Brain? Essentialism in our Cognition of Some Social Categories." Current Antropology, 42(4): 515-554.

Gravlee, C. C.; Bernard H. R.; Leopard, W. R. 2003. „Heredity, Environment, and Cranial Form: A Reanalysis of Boas's Immigrant Data.“ American Anthropologist, 105(1): 125-138.

Hacking, I. 1999. The Social Construction of What? Cambridge, MA: Harvard University Press.

Halloway, R. L. 2002. „Head to Head with Boas: Did He Err on the Plasticity of Head Form?“ Proceedings of the National Academy of Science of the United States of America, 99(23): 14622-14623.

Harpending, H. C.; Sherry, S. T.; Rogers A. R.; Stoneking, M. 1993. „The Genetic Structure of Ancient Human Populations.“" Current Antropology, 34(4): 483-96.

Harrison, G. A. 1969. „The Race Concept in Human Biology.“ In G.A. Harrison, J. Peel (eds) Biosocial Aspects of Race: Proceedings of the 5th Annual Symposium of the Eugenics Society. London, Sept. 1968 (Journal of Biosocial Science, Suppl. No. 1). Oxford: Blackwell Scientific Publications.

Harrison, G. A.; Peel, J. (eds) 1969. Biosocial Aspects of Race: Proceedings of the $5^{\text {th }}$ Annual Symposium of the Eugenics Society. London, Sept. 1968 (Journal of Biosocial Science, Suppl. No. 1). Oxford: Blackwell Scientific Publications.

Hawks, J.; Wolpoff, M. H. 2003. „Sixty Years of Modern Hum an Origins in the American Anthropological Association." American Anthropologist, 105(1): 89-100.

Hirschfeld, L. A. 1996. Race in the Making: Cognition, Culture, and the Child's Construction of Human Kinds. Cambridge, MA: MIT Press.

Hirschfeld, L. A. 1998. „Natural Assumptions - Race, Essence and Taxonomies of Human Kinds." Social Research, 65(2): 331-50.

Hooton, E. A. (1940) Why Men Behave Like Apes, and Vice Versa. Princeton, NJ: Princeton University Press.

Hooton, E. A. 1946. Up From the Ape. New York: Macmillan.

Hulse, F. S. 1969. „Ethnic, Caste and Genetic Miscegenation.“ In G.A. Harrison, J. Peel (eds) Biosocial Aspects of Race: Proceedings of the 5th Annual Symposium of the Eugenics Society. London, Sept. 1968 (Journal of Biosocial Science, Suppl. No. 1). Oxford: Blackwell Scientific Publications, s. 31-41

Huxley, J. S. 1938. „Clines: An Auxiliary Taxonomic Principle.“ Nature, 42: 219. 
Huxley, J. S. 1939. „Clines: An Auxiliary Method in Taxonomy.“ Bijdragen tot de dierkunde, 27: 491-520.

Huxley, J.; Haddon, A. C. 1935. We Europeans: A Survey of 'Racial' Problems. London: Jonathan Cape.

Kitcher, P. 2003. In Mendel's Mirror: Philosophical Reflections on Biology. New York: Oxford University Press.

Lévi-Strauss, C. 1958. Race and History. Paris: UNESCO.

Lewontin, R. C. 1991. Biology as Ideology: The Doctrine of DNA. Concord, Ont.: Anansi Press.

Livingstone, F. B. 1962. „On the Non-existence of Human Races.“ Current Antropology, 3(3): 279-81.

Macbeth, H. 1993. „Ethnicity and Human Biology. In M. Chapman (ed.) Social and Biological Aspects of Ethnicity. Oxford: Oxford University Press, s. 47-84.

Marks, J. 2000. „Ashley Montagu, 1905-1999.“Evolutionary Antropology, 9(3): 111-112.

Martin, G. W. 1963. „Concerning Ashley Montagu and the Term "Race”." American Anthropologist, 65(2): 402-403.

Mayr, E. 1997. This is Biology. Cambridge, MA: Belknap Press.

Mayr, E. 2004. „Happy Birthday: 80 Years of Watching the Evolutionary Skenery.“ Science, 305(5680): 46-47.

Milan, A.; Hamm, B. 2004. „Mixed Unions.“ Canadian Social Trends. Statistics Canada - Catalogue, 11-008.

Molnar, S. 2002. Human Variation: Races, Types, and Ethnic Groups. Upper Saddle River, NJ: Prentice Hall.

Montagu, A. 1941. „The Concept of Race in the Human Species in the Light of Genetics.“ Journal of Heredity, 32: 243-247.

Montagu, A. 1942a. Man's Most Dangerous Myth: The Fallacy of Race. New York: Columbia University Press.

Montagu, A. 1942b. „The Genetical Theory of Race, and Anthropological Metod.“ American Anthropologist, 44(3): 369-75.

Montagu, A. 1945. „Some Anthropological Terms: A Study in the Sytematics of Confusion.“ American Anthropologist, 47(1): 119-33.

Montagu, A. 1962. „The Concept of Race.“ American Anthropologist, 65(5): 919-928.

Montagu, A. 1963. „Regarding Montagu’s Use of “Ethnic Group.“ American Anthropologist, 65(6): 1352-1353.

Montagu, A. 1965. „On the Concept, “Ethnic Groups.“ Current Antropology, 6(3): 326.

Montagu, A. 1997. Man's Most Dangerous Myth: The Fallacy of Race. 6th edn. Walnut Creek, CA: AltaMira Press.

Polgar, S. 1964. „An Operational Approach to “Race.“ American Anthropologist, 66(2): 423426.

Richerson, P. J.; Boyd, R. 2005. Not by Genes Alone: How Culture Transformed Human Evolution. Chicago: University of Chicago Press.

Schwartz, M.; Wiggins, O.; Norka, M. 1995. „Prototypes, Ideal Types, and Personality.“ Disorders: The Return to Classical Phenomenology, s. 417-432. Livesley (ed.) The DSMIV Personality Disorders. New York: Guilford Press. 
Sparks, C. S.; Jantz, R.L. 2002. „A Reassessment of Human Cranial Plasticity: Boas Revisited." Proceedings of the National Academy of Science of the United States of America, 99(23): 14636-14639.

Weber, M. 1949. [1903-1917] The Methodology of the Social Science. New York: Free Press.

Weber, M. 1998. Metodologie, sociologie a politika. Praha: Oikoymenh, s. 44.

Wilson, R. A. 2004. „Critical Review of Philip Kitcher's.“ In Mendel's Mirror: Philosophical Reflections on Biology', Human Nature Review, 4: 1-13.

Wolpoff, M. H.; Caspari, R. 1997. Race and Human Evolution. New York: Simon and Schuster.

Wolpoff, M. H.; Caspari, R. 2000. „Multiregional, Not Multiple Origins.“ American Journal of Physical Antropology, 112(1): 129-36.

Wolpoff, M. H.; Xinzhi, W.; Thorne, A. 1984. „Modern Homo Sapiens Origins: A General Theory of Hominid Evolution Involving the Fossil Evidence from East Asia." In F.H. Smith, F. Spencer (eds) The Origins of Modern Humans: A World Survey of the Fossil Evidence. New York: Alan R. Liss, s. 441-483.

\section{Autor}

Michael Billinger získal v roce 2006 doktorát z fyzické antropologie na univerzitě v Albertě. Jeho výzkumným zájmem je kraniální morfologie, regionální variabilita, etnogeneze, forenzní antropologie, biologická taxonomie a filozofie biologie. Jeho disertační práce na téma „Za rasové paradigma: Nové perspektivy na biologickou variabilitu člověka“ poskytuje srozumitelnou analýzu „rasového problému“ $v$ antropologii, přičemž tyto perspektivy zkoumá jak z teoretického, tak i z metodologického hlediska. Billinger pracuje jako analytik Úřadu pro informace a utajení u policie v Edmontonu (Office for Information and Privacy at the Edmonton Police Service) v kanadské Albertě.

Kontakt:msb3@ualberta.net 